\title{
Root traits with team benefits: understanding belowground interactions in intercropping systems
}

\author{
Z. Homulle • T. S. George • A. J. Karley
}

Received: 21 August 2020 / Accepted: 21 September 2021 / Published online: 2 December 2021

(C) The Author(s) 2021

\begin{abstract}
Background The potential benefits of intercropping are manifold and have been repeatedly demonstrated. Intercropping has the potential to create more productive and resilient agroecosystems, by improving land utilisation, yield and yield stability, soil quality, and pest, disease and weed suppression. Despite these potential benefits, significant gaps remain in the understanding of ecological mechanisms that govern the outcomes when crop species are grown together. A major part of plant-plant interactions takes place belowground and these are often overlooked.
\end{abstract}

Responsible Editor: Ismail Cakmak.

Supplementary Information The online version contains supplementary material available at https://doi. org/10.1007/s11104-021-05165-8.

Z. Homulle $\cdot$ T. S. George $(\bowtie) \cdot$ A. J. Karley

Department of Ecological Sciences, the James Hutton Institute, Invergowrie, Dundee DD2 5DA, UK

e-mail: Tim.George@hutton.ac.uk

\section{Z. Homulle}

Department of Agroecology and Environment, ISARALyon, 23 Rue Jean Baldassini, 69364, CEDX 07 Lyon, France

Z. Homulle

Faculty of Biosciences, Department of Plant Sciences, Norwegian University of Life Sciences, P.O. Box 5003, NO-1432 Ås, Norway
Scope This review synthesises current evidence for belowground plant-plant interactions of competition, niche differentiation and facilitation, with the aim of identifying root traits that influence the processes contributing to enhanced performance of intercrops compared with monocultures. We identify a suite of potentially complementary root traits for maximising the benefits of intercropping. These traits underpin improved soil exploration, more efficient resource use, and suppression of soil-borne pathogens and pests in intercrops.

Conclusion This review brings together understanding of the mechanisms underpinning interactions between intercropped roots, and how root traits and their plasticity can promote positive outcomes. Root trait 'ideotypes' for intercropped partners are identified that could be selected for crop improvement. We highlight the importance of examining belowground interactions and consider both spatial and temporal distribution of roots and rhizosphere mechanisms that aid complementarity through niche differentiation and facilitation. Breeding of crop ideotypes with specific beneficial root traits, combined with considerations for optimal spatio-temporal arrangement and ratios of component crops, are essential next steps to promote the adoption of intercropping as a sustainable farming practice. 
Keywords Complementarity · Disease suppression · Facilitation · Niche differentiation . Nutrient uptake $\cdot$ Root distribution $\cdot$ Root-root interactions $\cdot$ Selection effects $\cdot$ Trait plasticity

\section{Introduction}

Prior to the "fossilization" of agriculture with chemical fertilizers and pesticides, cultivation of crop mixtures was a common agricultural practice (Mikić et al. 2015). Intercropping, also referred to as mixed cropping, companion cropping or polyculture, is the agroecological practice of cultivating two or more crops simultaneously. The component crops of an intercropping system are often from different species and different plant families, although it can refer to different varieties or cultivars of the same crop grown in variety mixtures (Lithourgidis et al. 2011). Intercropping has been widely practised by farmers for millennia and is still present in various cropping systems around the world. For example, in Mexico and Guatemala farmers often intercrop maize with beans, squash and other crops, according to ancient milpa traditions (Isakson 2009). In rural sub-Saharan Africa, intercropping is a common practice aimed at minimizing risks associated with monocultures, with the predominant crop combinations being maize, bean/cowpea and pumpkin (Bedoussac et al. 2018).

Features of an intercrop system differ around the world, depending on local climate, soil conditions, economic situation, and preferences of the local community (Lithourgidis et al. 2011). The different types of intercrop systems can be categorised based on the spatial and temporal variation of the crop mixture. These types of intercropping are usually divided into four main categories:

1. Mixed intercropping or mixed cropping: the cultivation of crops that are randomly mixed in the available space with no distinct row arrangement.

2. Row intercropping: two or more crops are cultivated in separate alternate rows.

3. Strip cropping: several rows (= strip) of crops are alternated with several rows of another crop. Strips are wide enough to allow the use of modern equipment, but narrow enough for the crops to interact.
4. Relay intercropping: component crops are not sown and harvested at the same time, but the life cycle of one crop overlaps that of the other. Relay intercropping can be practised independent of spatial arrangement.

The spatial arrangement is important because it indicates the number of conspecific and non-conspecific neighbours. For example, in mixed intercropping a plant would have fewer conspecific neighbours than in strip intercropping. As a result, plant-plant interactions of different species are fewer in strip intercropping than in mixed intercropping.

Even though most crops in intensive agricultural systems are grown as sole crops, there is renewed interest in adopting intercropping practices, due to the potential for positive outcomes from intercrop systems (Bedoussac et al. 2018). A global metaanalysis found that the overall yield gain in maizebased intercrop systems was $1.5 \pm 0.1 \mathrm{Mg} \mathrm{ha}^{-1}$ ( $\mathrm{Li}$ et al. 2020a), indicating that intercrop systems could have larger absolute yields than monocrop systems. It is often assumed that benefits of intercropping are only associated with low-input systems, but benefits may be even greater if stresses are relieved ( $\mathrm{Li}$ et al. 2020a). For instance, absolute yield gains in high input, high output maize-based intercrop systems have been found to be about four times larger than those without maize and using a low-input intercropping strategy ( $\mathrm{Li}$ et al. 2020a). Intercropping systems have been shown not only to boost crop productivity (Qin et al. 2013; Li et al. 2020a) and improve land utilization efficiency (Agegnehu et al. 2008), but can also enhance soil quality (Cong et al. 2015), suppress pests, diseases and weeds (Jensen et al. 2015), increase yield stability (Raseduzzaman and Jensen 2017), and reduce dependency on fertilisers and risks of nitrate leaching compared with sole cropping (Corre-Hellou et al. 2006; Hauggaard-Nielsen et al. 2003). These benefits, however, are not always achieved, partly due to incomplete knowledge about the plant characteristics that optimise interactions between intercropped plants, particularly those that occur belowground.

While there has been substantial evidence for temporal niche differentiation contributing to overyielding aboveground ( $\mathrm{Li}$ et al. 2020b), less is known about belowground processes (Brooker et al. 2015). The relative contribution of belowground 
interactions to yield advantages in intercropping, through increased water and nutrient uptake, can be substantial (Zhang et al. 2001; Mu et al. 2013). Although progress has been made towards a better understanding of belowground interactions between intercropped plants, significant gaps remain regarding the mechanisms. Studying belowground phenomena is more challenging than aboveground interactions due to methodological limitations. Many studies focussing on plant interactions can follow the outcome of interactions dynamically aboveground, while belowground interactions can often only be measured at the end of an experiment via destructive harvesting (Faget et al. 2013). Furthermore, demonstrating the belowground mechanisms responsible for overyielding in intercrop systems can be difficult (Duchene et al. 2017). Studies which show overyielding in terms of biomass, while simultaneously demonstrating greater $\mathrm{N}$ or $\mathrm{P}$ uptake or larger root biomass, cannot distinguish whether greater $\mathrm{N}$ or $\mathrm{P}$ uptake drives overyielding or whether larger root biomass is responsible for enhanced nutrient acquisition. In fact, both outcomes could be the consequence, rather than the cause, of overyielding.

Improving our understanding of mechanisms and processes at play between intercropped roots and identifying knowledge gaps in belowground interactions is key for advancing intercropping (Ma et al. 2019). In particular, identifying specific root traits which can promote beneficial plant-plant interactions and minimise crop-crop competition would be a step forward to design crops suitable for intercropping. Here we look in more detail at recent advances in understanding of how intercropped roots behave and provide a synopsis of key findings on root-root interactions. This review aims to 1) provide an overview of the interactions taking place between intercropped roots, 2) summarise evidence for root traits regulating interactions in intercropped roots compared with sole cropped roots, and 3) recommend root traits of importance for maximising the benefits of intercropping. By doing so, this review highlights the need to consider belowground interactions as critically as aboveground, by measuring belowground processes and considering both spatial distribution of roots and mechanisms in the rhizosphere that aid complementarity through niche differentiation and facilitation at a range of temporal and spatial scales which are relevant to biophysical processes in the soil (i.e. nutrient and water dynamics, and interactions with microbial facilitators and pathogens).

Underlying mechanisms of belowground interactions in intercrop systems

Several mechanisms have been conceptualised to explain overyielding in diverse systems. Intercropping leads to relatively small increases in plant diversity, comprising two or more crop species bred for high productivity, and it cannot be discounted that many of the apparent benefits associated with intercropping, some highlighted in this review, are due to selection effects (Loreau and Hector 2001) which favour dominance by a high yielding species. The relative importance of selection effects is also likely to be determined by crop spatial arrangement: in strip intercrops in China, only $10 \%$ of the yield gain was due to selection effects and the remainder was explained by complementarity effects ( $\mathrm{Li}$ et al. 2020b). Complementarity effects occur when niche space (i.e. physical, chemical and biological resources) is used more completely as more species are added in (niche differentiation), or when interactions between neighbouring plants have beneficial outcomes for at least one of the neighbours (facilitation) (Brooker et al. 2021; Loreau and Hector 2001). Complementarity is thus a two-sided interaction, although it is often not clear whether niche differentiation or facilitation are underlying these effects (Loreau and Hector 2001). Intercrops showing positive selection effects will outperform the average monoculture but will not exceed the performance of the best species in monoculture, whereas complementarity effects promote the overall performance of species in mixtures and lead to greater net resource use (Loreau and Hector 2001; Schöb et al. 2015). In this review, we focus on identifying root traits that promote better use of available niche space and/or facilitative processes that enhance resource capture as the desirable goals for intercrop improvement, but we also highlight studies revealing root traits that might drive selection effects in high yielding intercrops. 


\section{Root traits for complementary resource use}

\section{Complementarity through niche differentiation}

Successful intercrop systems can be achieved by growing crops together which complement each other in spatial niche occupation (e.g. tall and short). Crops that occupy different niches may use resources more completely compared with sole crops, due to differential use of resources in space, time or different forms (Ehrmann and Ritz 2014).

\section{Spatial niche differentiation}

To achieve complementarity in space, intercropped plants with different rooting patterns should be considered. One such example would be growing deeprooted and shallow-rooted crops together, allowing access to distinct volumes of soil (Hassan et al. 2019), which could, in theory, lead to a deeper and more even distribution of roots in the crop system (Fig. 1A). This allows for a greater exploitation of a larger soil volume and improved access to relatively immobile nutrients in the intercrop system, compared with a monocrop system (Gebru 2015). Improved exploitation of belowground resources can alleviate belowground competition and promote species coexistence.

However, spatial differentiation is not simply a result of intrinsic or genetic differences in speciesspecific root architectures; it can also result from the plasticity of root systems, whereby root-root interactions can alter biomass allocation and modify root distributions (Chen et al. 2020). Variable responses to the presence of neighbour roots have been observed; some species demonstrate avoidance strategies, where roots grow away from the neighbour, whereas other species tend to grow roots near neighbour roots and aggregate (Zhang et al. 2020a). Neighbour-induced root responses are likely to be common in intercropping systems and can enable plants to avoid severe competition and enhance resource uptake efficiency (Schiffers et al. 2011).

Agroforestry systems, where trees are used as an intercrop component, provide a clear example of spatial niche differentiation, since trees tend to grow their roots in deeper layers than the annual intercrops. Moreover, spatial niche differentiation is important for intercrop systems with a large number of non-conspecific neighbours (i.e. mixed intercropping), whereas in strip intercropping, spatial differentiation only occurs in at the edges of the strips, where non-conspecific neighbours can interact.

\section{Temporal niche differentiation}

Niche differentiation through time in size, position and activity of the root systems of component crops is particularly important in determining resource capture, biomass production and ultimately yields of the intercropped plants (Fukai and Trenbath 1993). Component crops showing temporal differentiation mature at different times (Fig. 1B). As a result, the growth patterns of the crops will also differ in time, with the accompanying nutrient and water demands occurring with a time displacement (Gebru 2015). Component plants with similar growth durations will only have the advantage of spatial complementarity, whereas the association of crops with different growth durations results in improved resource utilization in both space and time.

Differences in maturity and requirement of resources for growth of the component crops can be due to genetic differences or manipulation of planting dates. The latter is the case in relay intercropping, a specific cropping practice where component crops are not sown and harvested at the same time, but the life cycle of one crop overlaps that of the other. In such cropping systems, interspecific competition enhances the growth and yield of the dominant crop, whereas the subordinate crop's growth is weakened by interspecific competition in the co-growth stage ( $\mathrm{Li}$ et al. 2001a). After harvest of the dominant crop, the second crop has a period of growth alone, during which it can recover and take up more resources, thereby retaining or even increasing its yield compared with sole cropping ( $\mathrm{Li}$ et al. 2001b). Roots of the dominant crop, which may have been left in the soil after harvest, will decompose and release nutrients into the soil profile, becoming available for the second crop.

Belowground interactions can be studied at scales spanning the morphology of the whole root system to sites of nutrient acquisition at fine scale (Isaac and Borden 2019). The theory of spatial and temporal niche differentiation between plants provides a useful framework for explaining coexistence at the level of the whole root system. Due to the destructive nature of root sampling, complementarity 
A) Spatial niche complementarity

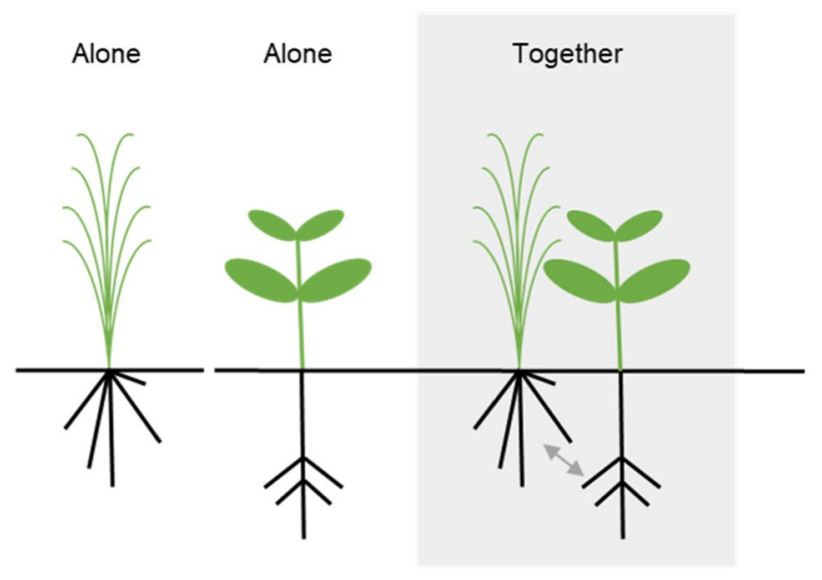

B) Temporal complementarity

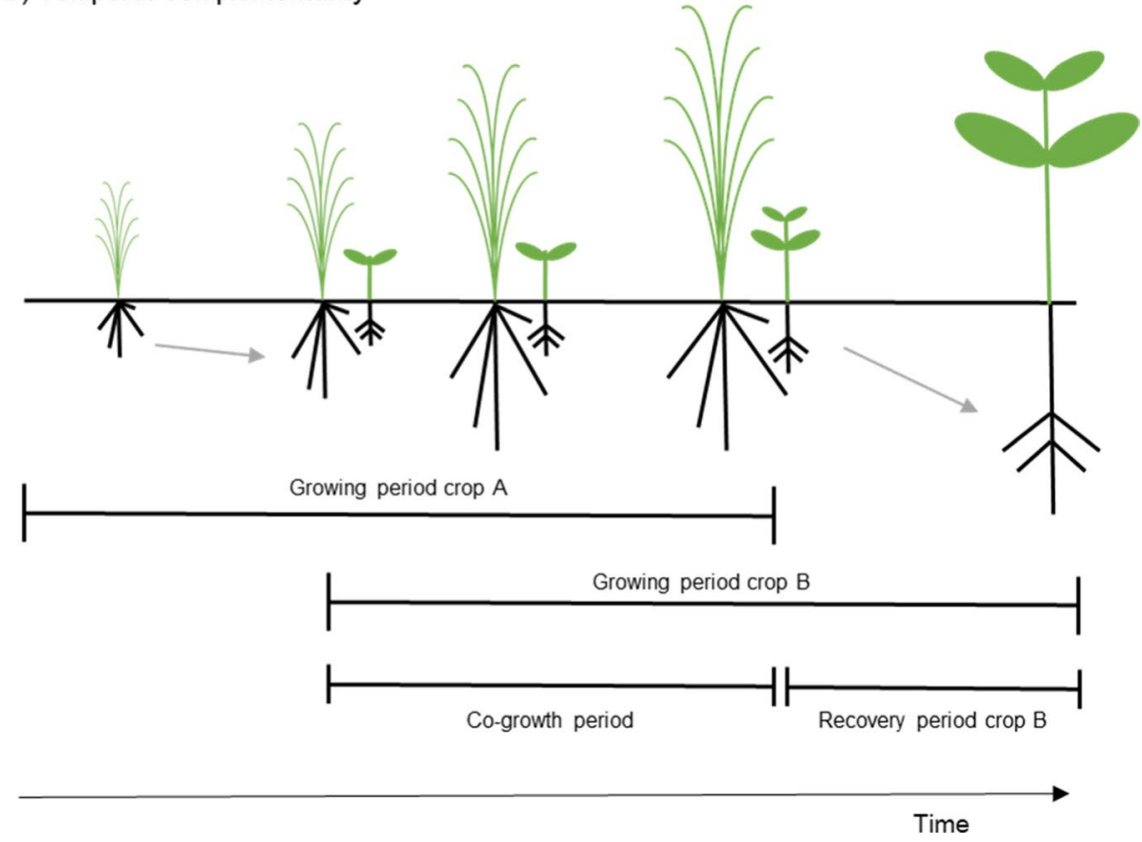

Fig. 1 Species with differentiated root traits (e.g. rooting depth) (A) Spatial niche differentiation: plants when in monoculture will utilise the soil volume within which they place their roots, but when sown together plants with different rooting depths will be able to grow together and use the soil volume efficiently. (B) Temporal niche differentiation can be achieved by planting crops

is often studied at only a few developmental time points and in a restricted set of soil conditions (Faget et al. 2013), but it should be noted that plants respond to multiple signals from a highly at different times. The first crop can explore the soil space freely without competition during initial growing stages. The second crop will likely experience interspecific competition, leading to reduced growth. After the first crop is harvested, the second crop can recover its growth, due to reduced competition for available soil resources

heterogeneous and dynamic soil environment. The distribution of a root system changes in response to heterogeneously distributed soil resources, the nutrient status of the plant, and intrinsic restrictions 
of the genotype (Isaac and Borden 2019). For example, a plant can deplete resources in the area surrounding its roots, which may discourage root growth by a neighbouring plant root into that same area. Furthermore, it should be noted that the placement of the whole root system does not necessarily indicate root activity; roots nearer the soil surface might be more active in taking up nutrients, due to soil resources being more concentrated in the topsoil layer as a result of fertilisation, irrigation and litter decomposition on the soil surface.

\section{Resource differentiation}

Although plants essentially use the same resources (i.e. light, water, nutrients), the preferential use of these resources between species can differ. Similarly to spatial differentiation, resource differentiation is more evident in intercrop systems with a high number of non-conspecific neighbours (i.e. mixed intercropping), while in strip intercropping, these processes only occur at the edges of the strips, where non-conspecific neighbours can interact. Resource differentiation occurs when crops use different portions of the available resources. A good example of this is the preference of certain plants for one chemical form of available nitrogen $(\mathrm{N})$ over another, e.g. nitrate $\left(\mathrm{NO}_{3}{ }^{-}\right)$, ammonium $\left(\mathrm{NH}_{4}{ }^{+}\right)$, and atmospheric nitrogen $\left(\mathrm{N}_{2}\right)$. Some plant species produce more biomass or accumulate greater amounts of $\mathrm{N}$ when growing on one $\mathrm{N}$ source compared with another, indicating preferential uptake and use of different $\mathrm{N}$ forms (Britto and Kronzucker 2013). Despite the importance of $\mathrm{N}$ in agricultural systems, classification of crop preferences for $\mathrm{NO}_{3}{ }^{-}$or $\mathrm{NH}_{4}{ }^{+}$is lacking. This is in part because environmental variables and interactions between plants can shift $\mathrm{N}$ preference (Boudsocq et al. 2012).

There is evidence that plants can shift their preference for one chemical $\mathrm{N}$ form to another when intercropped. Liu et al. (2020a) investigated the effect of intercropping on the $\mathrm{N}$ uptake of two grass species. When monocropped, Avena sativa had only slightly higher rates of $\mathrm{NO}_{3}{ }^{-}$uptake than of $\mathrm{NH}_{4}{ }^{+}$, while monocropped Agropyron cristatum showed considerably higher uptake rates of $\mathrm{NO}_{3}{ }^{-}$than $\mathrm{NH}_{4}{ }^{+}$in both upper and deeper soil layers. Intercropping altered the $\mathrm{NO}_{3}{ }^{-}$and $\mathrm{NH}_{4}{ }^{+}$uptake of the two grasses. In the upper soil layer, uptake of $\mathrm{NO}_{3}^{-}$by $A$. sativa was $50 \%$ less in the intercropped system than in the monocropped system, whereas uptake of $\mathrm{NO}_{3}{ }^{-}$by $\mathrm{A}$. cristatum was two-fold greater in the intercropped system. In the deeper soil layer, intercropping did not significantly change $\mathrm{NH}_{4}{ }^{+}$and $\mathrm{NO}_{3}^{-}$uptake by A. sativa but $\mathrm{NO}_{3}{ }^{-}$uptake by $A$. cristatum decreased. The aboveground and total biomass of intercropped A. sativa was 1.3 times greater than monocropped A. sativa, but the biomass of A. cristatum did not change between cropping systems; this might reflect selection effects, where dominance of $A$. sativa leads to increased yield, or it might result from complementarity effects on nitrogen availability and uptake. Neither species showed a change in root biomass, however, indicating that altered root $\mathrm{N}$ uptake by the intercropped species was driven by direct effects on root transporter activity to avoid competition for $\mathrm{N}$ forms and/or due to changes in A. sativa shoot $\mathrm{N}$ demand. Improving our understanding of the plasticity of this preferential use of $\mathrm{N}$ forms, and which species combinations complement each other to optimise $\mathrm{N}$ use, could be beneficial for intercropping systems.

Atmospheric $\mathrm{N}_{2}$ is another component of the $\mathrm{N}$ resource pool for plants. When legumes, which have the ability to fix atmospheric $\mathrm{N}_{2}$, are combined with a strongly $\mathrm{N}$ competitive crop, such as cereals, the dominant crop usually takes a larger proportion of the soil N, thereby 'forcing' the legume to rely more on $\mathrm{N}_{2}$ fixation than when it is grown as a sole crop (Fan et al. 2006; Stomph et al. 2020). It is well documented that, when intercropped, legumes increase biological nitrogen fixation activity compared with monocultures (Fan et al. 2006). For example, Chapagain and Riseman (2014) found that the percentage of $\mathrm{N}$ fixed by pea (Pisum sativum L.) increased when intercropped with barley (Hordeum vulgare L.), while Tsialtas et al. (2018) demonstrated similar findings for certain pea-oat mixtures. As a result of the greater reliance of the legume on atmospheric $\mathrm{N}_{2}$, more soil $\mathrm{N}$ is available for the component non-legume.

\section{Complementarity through facilitation}

Facilitation is a process that occurs in many plant communities (Valiente-Banuet et al. 2006) when one species is positively affected by the presence of another, usually through the improvement of resource availability and other environmental growth 
conditions. In contrast to niche differentiation, facilitation is often a one-sided process, whereby at least one species benefits (Montesinos-Navarro et al. 2012). The benefits of facilitative interactions can be maintained over the whole co-growth period (Valiente-Banuet and Verdú 2008). Belowground facilitative interactions in intercropping systems can result in enhanced nutrient and water acquisition, often aided by mycorrhizal networks. Facilitative interactions concerning the availability of nitrogen, phosphorus and water resources in the soil are considered below.

\section{Nitrogen}

Root facilitative interactions in legume/non-legume intercropping systems can result in belowground transfer of symbiotically fixed $\mathrm{N}_{2}$ from legumes to intercropped non-legumes (Pirhofer-Walzl et al. 2012; Frankow-Lindberg and Dahlin 2013). There are several mechanisms involved in $\mathrm{N}$ transfer between intercropped species (Fig. 2A). Nitrogen can be relocated from plant to plant directly by root-root contacts via root exudates or through mycorrhizal hyphal networks (Heijden and Horton 2009; Selosse et al. 2006). Nitrogen can also be transferred indirectly through rhizodeposition, the release of $\mathrm{N}$ from decomposed belowground parts of legumes and root exudates (Tsialtas et al. 2018). The proximity of the intercropped roots, and thus the intercrop sowing pattern, might be less important regarding nitrogen facilitation: for $\mathrm{N}$ transfer through mycorrhizal networks or rhizodeposition, roots do not need to be close in space or time, respectively (Fig. 2A).

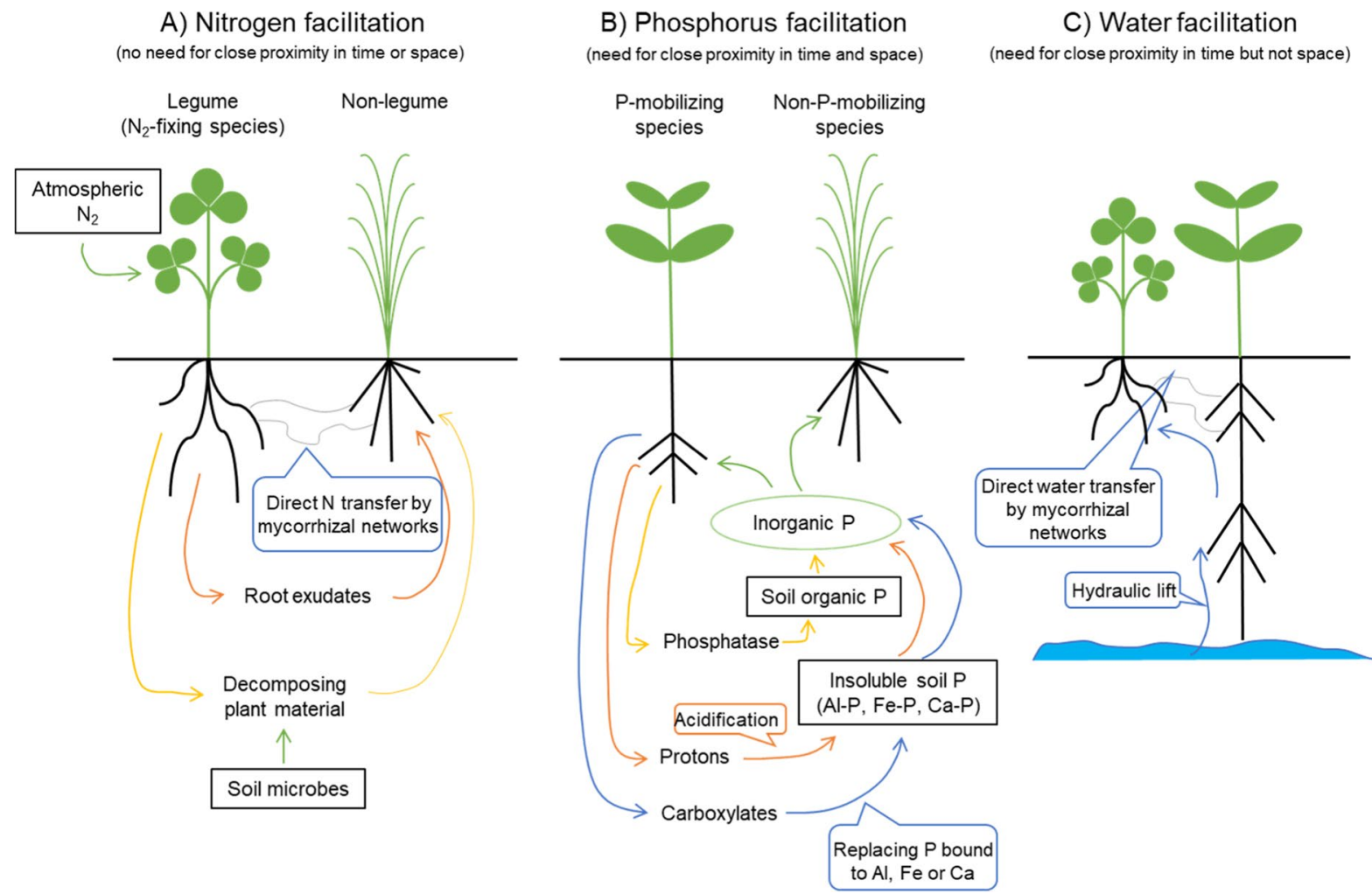

Fig. 2 Interspecific facilitation of nitrogen $(\mathrm{N})$, phosphorus (P) and water acquisition. Belowground transfer mechanisms of $\mathrm{N}$ from legumes to non-legumes include direct transfer by mycorrhizal fungi, root exudates, and indirectly through the decomposition of plant material, such as dead roots and plant litter (A) (adapted from Thilakarathna et al. 2016). Belowground mobilizing mechanisms of soil organic $\mathrm{P}$ and insoluble soil $\mathrm{P}$ include secreting phosphatases, or exudation of carboxylates or protons. The soluble inorganic $\mathrm{P}$ can then be utilized by both P-mobilizing and non-P-mobilizing plant species (B) (adapted from Li et al. 2014). Hydraulic lift and transfer of water to component crops plays an important role in the facilitation of water acquisition (C). Mycorrhizal networks can also contribute to the transfer of water between neighbouring plants 
It can be difficult to establish if facilitative root interactions in a legume/non-legume intercropping system enhance the growth of either or both species, and that over-yielding is not just due to differentiation in $\mathrm{N}$ source use. Quantification of both $\mathrm{N}_{2}$ fixation and $\mathrm{N}$ transfer from legumes to non-legumes, whether through root exudates, nodule senescence or mycyorrhizal connections, can be achieved using $\mathrm{N}$ isotope labelling techniques, of which the ${ }^{15} \mathrm{~N}$ natural abundance method can be practiced reliably in the field (Tsialtas et al. 2018). Large variability in proportions of fixed $\mathrm{N}_{2}$ transferred to non-legumes has been observed. In a review of the literature, Thilakarathna et al. (2016) found that values reported for the proportion of $\mathrm{N}$ transferred from legumes to companion grasses ranged from 0 to $73 \%$, depending on the legume species and cultivar. However, high estimates should be viewed with caution, and values between 0 and $15 \%$ of $\mathrm{N}$ transferred seem to be more realistic (Peoples et al. 2015). Other factors influencing $\mathrm{N}$ transfer include abiotic factors, such as water stress, soil $\mathrm{N}$ availability, application of $\mathrm{N}$ fertilizer, and biotic factors like root contact, plant density, growth stage, and defoliation (Islam and Adjesiwor 2018). Mycorrhizal networks can greatly stimulate the transfer of fixed $\mathrm{N}$, as has been observed from faba bean (Vicia faba L.) to wheat (Triticum aestivum L.) (Wahbi et al. 2016), and from alfalfa (Medicago sativa L.) to maize (Zhang et al. 2020b), although in the latter example labelled $\mathrm{N}$ was fed to leaves and therefore this was not a direct measure of $\mathrm{N}$ fixed and transferred by the legume.

Although increased nitrogen fixation by intercropped legumes is regarded as a process of resource differentiation (see above), increased $\mathrm{N}$ fixation might also be facilitated by the non-legume partner. Recent research into the mechanism(s) underpinning improved yield and $\mathrm{N}$ capture by maize/faba bean intercrops (Fan et al. 2006) has revealed that maize roots play a facilitating role. Elevated $\mathrm{N}$ fixation rate of intercropped faba bean was associated with increased root nodulation, even when $\mathrm{N}$ fertiliser was added ( $\mathrm{Li}$ et al. 2016b). Detailed analysis showed that bean root hair deformation, in response to inoculation with Rhizobium leguminosarum, increased in the presence of maize root exudates (but not barley or wheat root exudates) and this was associated with greater nodule acetylene reductase activity and increased expression in bean roots of genes involved in synthesis of flavonoid signalling compounds, regulation of root nodulation and $\mathrm{N}$ fixation ( $\mathrm{Li}$ et al. 2016b). Further analysis revealed that greater bean $\mathrm{N}$ fixation capacity was not only due to the direct facilitative effects of maize root exudates: these exudates also increased the abundance of specific bacterial groups in the bean rhizosphere that further enhanced $\mathrm{N}$ fixation gene expression in bean roots $(\mathrm{Hu}$ et al. 2021).

\section{Phosphorus}

Phosphorus $(\mathrm{P})$ is an important inorganic nutrient for plant growth, and often limits primary productivity in natural systems as well as cropping systems (Hinsinger 2001; Vance et al. 2003). Due to its highly immobile nature in soil, many plant species have developed strategies to acquire soil $\mathrm{P}$, such as the exudation of P-solubilizing compounds, like phosphatase and carboxylates, or by rhizosphere acidification (Richardson et al. 2009; Li et al. 2014) (Fig. 2B), which can also enhance (or reduce) the availability of other immobile nutrients ( $\mathrm{Li}$ et al. 2007; Zhang et al. 2010), and might lead to high and even toxic levels of aluminium $\left(\mathrm{Al}^{3+}\right)$ and manganese $\left(\mathrm{Mn}^{2+}\right)$ cations.

Plant species vary widely in their capacity to mobilize inorganic $\mathrm{P}$, and some $\mathrm{P}$ acquisition traits are species-specific. Species that secrete phosphatases or carboxylates, and thereby convert $\mathrm{P}$ into available forms, are considered P-mobilizing species, whereas species with a weak capacity to acquire bound soil $\mathrm{P}$ are non-P-mobilizing species (Li et al. 2007; 2014). Several studies have looked at the facilitative processes between intercropped plants in their P acquisition ( $\mathrm{Li}$ et al. 2007, 2014, 2016a, 2019; Zhang et al. 2016; Yu et al. 2020). When crops with different $P$ acquisition strategies are grown together, positive interactions can be expected (Tang et al. 2020). For example, faba bean facilitated $\mathrm{P}$ uptake when intercropped with maize (Zea mays L.), through rhizosphere acidification by releasing organic acids and protons, which mobilized insoluble inorganic $\mathrm{P}(\mathrm{Li}$ et al. 2007). This resulted in improved $P$ uptake, which was associated with over-yielding of intercropped maize, compared with monocropped maize. Li et al. (2016a) found similar results in a wheat/faba bean glasshouse experiment, where faba bean facilitated $\mathrm{P}$ uptake by wheat, through exudation of carboxylates including malate and citrate, and increased acid phosphatase 
activity. Other legumes have also been observed to facilitate P uptake: white lupin (Lupinus albus L.) roots exude large amounts of citrate to mobilize soil $\mathrm{P}$, depleting citrate extractable $\mathrm{P}$ and making $\mathrm{P}$ available to neighbouring wheat plants ( $\mathrm{Cu}$ et al. 2005). Intercropped chickpea (Cicer arietinum L.) secretes acid phosphatase into the rhizosphere, thereby mineralising organic $\mathrm{P}$ and increasing $\mathrm{P}$ acquisition by neighbouring maize (Li et al. 2004).

Phosphorus mobilizing species benefit directly from improved $\mathrm{P}$ availability and may create indirect benefits for neighbouring non P-mobilizing plants by facilitating $\mathrm{P}$ uptake provided that the roots are in close proximity (Giles et al. 2018). The influence of root exudates from one plant on soil nutrient availability to a neighbouring plant will be largely determined by the spatial proximity of their roots (Fig. 2B) and by the ability of the neighbouring plant to respond (e.g. through altered root placement: Yu et al. 2020). Intercrop systems with a greater degree of spatial mixing would thus be more efficient at facilitating $\mathrm{P}$ uptake, and sowing arrangements that influence the intimacy of crops in an intercropping system should be considered to maximise facilitative processes.

Another possible pathway of $\mathrm{P}$ transfer between plants is though mycorrhizal networks. Although mycorrhizae contribute significantly to the $\mathrm{P}$ nutrition of their host plants, their role in plant-plant nutrient transfer is unclear, and might even be too small to be of importance for plant phosphorus nutrition (Selosse et al. 2006). Differentiation of P-uptake has also been hypothesised, when two intercropped species use distinct pools of soil $\mathrm{P}$ (Turner 2008; Hinsinger et al. 2011).

\section{Water}

The combination of deep-rooted and shallow-rooted species can lead to spatial niche differentiation, allowing each species to access water in different parts of the soil profile, and facilitation whereby deep-rooted species aid shallow-rooted species in their water acquisition. Hydraulic lift is the process where soil water is translocated by plant roots from wet to dry areas, driven by a water potential gradient (Richards and Caldwell 1987). Hydraulic redistribution of soil water by deep-rooted species usually occurs during the night when plant transpiration is low or negligible. Redistribution of soil water from deeper soil layers to dry surface areas can be especially beneficial in dry regions where water sources are scarce. Moreover, hydraulic redistribution may also improve nutrient uptake because local increases in soil moisture can increase the mobility of nutrients which either move by mass flow or diffusion (Snyder et al. 2008; Matimati et al. 2014).

Isotope studies show that deep water sources are hydraulically lifted and transferred to neighbouring plants (Dawson 1993; Hawkins et al. 2009). There are two pathways by which neighbouring plants can access water redistributed by a deep-rooted plant through hydraulic lift: indirect transfer from one plant to another when water is driven out of the roots into the surface soil, or directly through mycorrhizal networks linking root systems of neighbouring plants (Prieto et al. 2012; Singh et al. 2019) (Fig. 2C). Interspecific transfer of modest amounts of water via hydraulic redistribution in intercropping systems has been documented between deep- and shallowrooted perennial forage legumes (Pang et al. 2013) and between annual crops, e.g. deep-rooted pearl millet (Pennisetum glaucum (L.) R.Br) and droughtsusceptible rice (Oryza sativa L.) (Izumi et al. 2018). Mycorrhizal networks can facilitate water transfer between two plants. For example, pigeon pea was able to hydraulically lift water from deeper soil layers to the topsoil, but only intercropped finger millet plants that were connected to pigeon pea via a common mycorrhizal network were able to utilize this water (Singh et al. 2019).

\section{Other essential resources}

Intercropping can also contribute to increased iron $(\mathrm{Fe})$ and zinc ( $\mathrm{Zn})$ uptake, and thereby increased nutritional quality of harvested grain (Zuo and Zhang 2009; Xue et al. 2016). For example, Fe and Zn concentrations in the shoots of peanut plants grown with barley, oats or wheat were significantly greater than those in monocrops (Zuo and Zhang 2008). Graminaceous plant species exude phytosiderophores in response to Fe deficiency to increase Fe and $\mathrm{Zn}$ availability and transport these nutrients from the rhizosphere to the root surface for uptake (Zuo and Zhang 2009). Intercropping non-phytosiderophore producing plants with graminaceaous plants could thus lead 
to enhanced $\mathrm{Fe}$ and $\mathrm{Zn}$ availability, assuming plant roots are in close proximity. Furthermore, alleviating Fe deficiency has been suggested as an explanation for increased $\mathrm{N}_{2}$ fixation in legumes (Tang et al. 1990), which could in turn lead to enhanced $N$ uptake in cereal-legume mixtures.

\section{Root traits contributing to suppression of soil-borne diseases and pests in intercrops}

The soil contains pathogens, which can be detrimental to crop yield especially when they accumulate in cultivated soils, and effective methods to control soilborne diseases are often lacking (Gao et al. 2014). Intercropping can suppress soil-borne pathogens in three ways: (i) by reducing host plant density, (ii) direct inhibition of pathogens by root exudates from intercropped plants and (iii) by plant-induced changes to the soil matrix that promote soil microbes antagonistic to pathogens (Fig. 3).

\section{Reduced host plant density}

It has been hypothesised that the dilution of host plants in more diverse systems disrupts the ability of pests to find and attack their intended host efficiently (Ratnadass et al. 2012), a theory that is supported by aboveground studies. Increased plant diversity also affects the prevalence of soil microbial pathogens (Mommer et al. 2018), possibly due to increased distance between host plant roots, which can reduce the severity of disease and pest infestations (Ehrmann and Ritz 2014).

Intercrops can also directly interfere with the onset of plant disease by reducing the dispersal of pathogen spores and by modifying environmental conditions to become less favourable for pathogens (Lithourgidis et al. 2011; Boudreau 2013). Roots of the non-susceptible partner crop can create a physical barrier that slows down the spread of the pathogen to infect susceptible neighbouring host plants (Ehrmann and Ritz 2014; Zhu and Morel 2018). Intercropping tomato (Solanum lycopersicum L.) with a forage grass, for example, reduced the incidence of tomato stem rot by 40 to $50 \%$ (Zhou et al. 2019) in this way. To reduce distance between conspecific roots and thus dispersal of pathogens, row or strip intercropping appears to be the most suitable intercrop pattern.
Direct inhibition by plants

Plants can release chemicals into the microenvironment that directly affect pathogen and pest survival (Meiners et al. 2012). Although these chemicals can be produced and released in all parts of the plant, when released through the roots, they can suppress harmful soil organisms, as they are toxic, deterrent or anti-feedant for one or various groups of soil-borne pathogens/parasites (i.e. fungi, nematodes or bacteria) or root-feeding herbivores. In intercrop systems, plants with the ability to produce and release these defensive compounds can act as a type of biological control: the release of chemicals by one plant root can suppress the pathogen or pest of another plant (Ehrmann and Ritz 2014). Suppressing harmful soil organisms through root exudates requires plants to be in close proximity, since root exudates do not travel far through the soil. Intercrop patterns whereby roots of non-conspecific neighbours can mingle with each other are most suitable for this direct way of suppressing pathogens.

For fungal soil-borne pathogens, chemicals released by intercropped species can protect neighbouring crop plants by inhibiting spore germination and mycelial growth, thereby reducing pathogen abundance in the soil (Zhu and Morel 2018). For example, intercropping watermelon (Citrullus lanatus (Trunb.) Matsum and Nakai) with rice can alleviate and control Fusarium wilt in the watermelon (Ren et al. 2008), as root exudates released by rice were shown to inhibit fungal spore germination by approximately $10 \%$ (Hao et al. 2010). Intercropping tomato with forage grass significantly reduced the incidence of tomato stem rot, although in vitro assays suggested that root exudates of intercropped tall fescue had only a small impact on the mycelium growth of the fungus Rhizoctonia solani (c. 10-15\% reduction in colony diameter across a range of concentrations and exposure times: Zhou et al. 2019). In citrus orchards in South China and Vietnam, the herb Ageratum conyzoides is often grown as an understory plant as its root exudates effectively inhibit spore germination of soil-borne pathogenic fungi (Rioba and Stevenson 2017). Kong et al. (2004) found reduced populations of pathogenic fungi (by up to 50\%) in soils collected from citrus orchard trees intercropped with $A$. conyzoides compared with non-intercropped citrus 


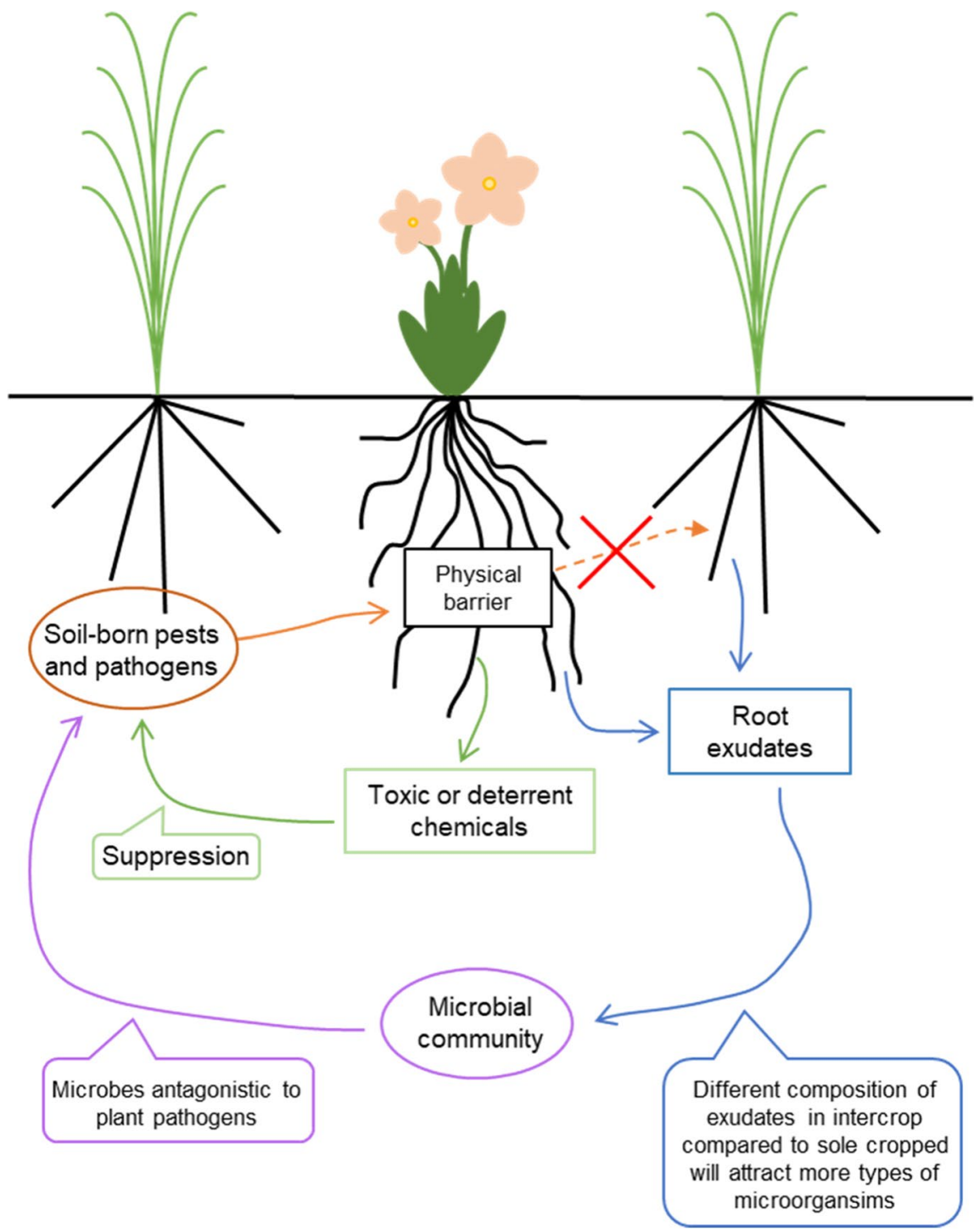

Fig. 3 Different pathways through which intercropping can supress soil-borne pathogens and pests. The root system of an intercrop species can create a physical barrier that slows down the spread of pathogens or pests to neighbouring host plants. Direct inhibition of pathogens can also occur via chemicals in

orchards, although the ability to supress the growth of individual pathogens was not investigated.

Plant-parasitic nematodes can also be inhibited by chemicals released by the roots of non-host plants. Several Asteraceae species have been shown to affect plant-parasitic nematodes negatively and can thus benefit neighbouring plants in an intercropping system (Tsay et al. 2004): marigold (Tagetes spp.) has been widely studied due to its protective potential root exudates from intercropped plants. Lastly, the roots of component crops release different exudates into the soil, attracting different types of microorganisms, changing the soil microbial community composition, with increased chances that some microbes will be antagonistic to plant pathogens

against plant-parasitic nematodes (Hooks et al. 2010). Root galling on soybean (Glycine $\max$ L.) was significantly reduced when intercropped with marigold compared with monoculture soybean (El-Hamawi et al. 2004). Similar results have been found in tomato, mulberry (Morus alba L.), and water spinach (Ipomoea reptans Poir.), all of which showed reduced root-knot galling when intercropped with marigold (Hooks et al. 2010). 
The use of toxic or deterrent root exudates in intercropping for suppression of root-feeding insects has not been widely addressed (Johnson et al. 2016). However, Björkman et al. (2008) studied how the glucosinolate content of cabbage (Brassica oleracea L.) is affected by intercropping with clover, and how this in turn influenced damage caused by turnip root fly (Delia floralis). The study showed that tissue concentrations of glucosinolates, which are important defensive compounds in Brassicaceae, typically decreased in response to intercropping, potentially due to plantplant competition. Although this might suggest that clover reduces the suppressive effects of cabbage root exudates on damage by turnip root fly larvae, intercropping studies using these two plant species showed reduced oviposition by $D$. floralis adults (Björkman et al. 2007), and smaller pupal weight of larvae (Björkman et al. 2009) on intercropped cabbage, suggesting intercropping influenced insect performance through multiple mechanisms.

\section{Microbial abundance, diversity and activity}

The diversity of organisms living in soils and especially those in the rhizosphere is largely influenced by plant species composition and diversity (Kowalchuk et al. 2002). Plants have species-specific effects on rhizosphere microbial communities, due to differences in the amount and composition of root exudates (Song et al. 2007b). Intercropping might affect the composition of root exudates released by the component crops, and therefore support microorganism communities differing in composition and function compared with sole cropping (Song et al. 2007a). For example, intercropping cucumber with garlic increased the abundance of soil bacteria and actinomycetes and decreased the abundance of fungi, compared with monocultures, and this was associated with increased soil alkaline phosphatase activity (Xiao et al. 2012). Soils cultivated with sugarcane intercropped with either peanut or soybean had greater microbial activity and abundance than soils of monoculture sugarcane (Solanki et al. 2019). In tree-based intercrop systems, greater soil microbial diversity has been observed compared with conventional monocropping systems (Lacombe et al. 2009). Greater microbial diversity and/or activity will increase the chances that some microbes will be antagonistic to plant pathogens (Ratnadass et al. 2012), increasing the capacity of intercropped soils to reduce disease severity (Dai et al. 2013; Medeiros et al. 2019). It is worth noting that intercropping could affect beneficial soil organisms, such as mycorrhizal fungi, through mechanisms highlighted here, and investigating these potential negative effects should not be neglected.

\section{Root plasticity in intercropping systems}

Plants are capable of modifying their root behaviour in response to both biotic and abiotic signals (Rabbi et al. 2017). As a result, a given plant genotype can produce alternative morphological or physiological phenotypes in response to different environmental conditions (Pigliucci 2001). This ability to change and adapt in response to variations in the belowground environment, termed plasticity, is important for plant adaptation to spatial and temporal variations in soil resources, but it is also expected to minimize competition between neighbouring plants. Morphological root plasticity, i.e. changing of root architectural traits, could minimise competitive root-root interactions between plants by decreasing the size of rooting zone overlap with neighbours, increasing spatial niche differentiation (Schiffers et al. 2011). In addition, physiological alterations in root nutrient uptake and the exudation of organic and inorganic compounds to increase nutrient uptake might facilitate the growth of component crop neighbours. Although in theory root plasticity would seem to be a beneficial characteristic, allowing plants to adapt to their changing environment, plasticity of certain root traits might not always be advantageous. For instance, the ability to 'overproduce' roots when competing with neighbouring individuals may be essential for plant survival in nature. However the plasticity of this trait may be disadvantageous in agricultural systems if it leads to plants allocating more biomass to their root system instead of harvestable plant parts, which may reduce crop yields (Weiner 2004).

The mechanisms and consequences of plasticity in root growth for interactions among plants are relatively unclear. The factors which can influence root behaviour when intercropped (e.g. identity of intercrop components, planting densities and spatial arrangements, water and nutrient availability, timing of planting/harvesting, and interactions with microbes and other belowground organisms), makes the quest 
to understand root plasticity difficult. Here, we present evidence for plasticity of several root traits in intercrops.

\section{Spatial root distribution}

Plants have highly variable responses to the presence of neighbours in how they distribute their roots; some species demonstrate avoidance (i.e. roots growing away from the neighbour), and some species tend to grow roots towards neighbours (root aggregation) (Zhang et al. 2020a). Even within the same species, genotypes can respond differentially to neighbouring roots. When sole cropped, eight winter faba bean genotypes did not differ in their horizontal and vertical root distribution. However, when intercropped with wheat, some faba bean genotypes increased the root horizontal spread, whereas other genotypes displayed minimal horizontal spread and instead grew more roots in deeper soil layers beneath those of the neighbouring wheat plants (Streit et al. 2019). Similarly, wheat roots grew deeper in the soil profile when intercropped with maize, and had $c .1 .5$ to twofold greater root length density (RLD) at all soil depths than when sole cropped ( $\mathrm{Li}$ et al. 2006). The roots of intercropped maize also showed increased RLD, particularly in upper soil layers (up to two-fold), but were limited in their lateral spread. These changes in root traits were associated with 1.5-fold greater $\mathrm{N}$ uptake and yield in wheat when intercropped, but no change in $\mathrm{P}$ uptake, while maize nutrient uptake and yield was unaffected. This indicates that root plasticity benefited wheat growth more than maize, indicating facilitative mechanisms were operating. In a maize/faba bean intercrop, both crops showed reduced RLD compared with sole crops, and a larger proportion of faba bean roots were found in the upper soil layers while intercropped maize allocated more mass to roots growing in deeper layers, reaching soil layers below the depth of faba bean roots ( $\mathrm{Li}$ et al. 2006). In this intercrop combination, faba bean and maize showed greater biomass (faba bean) or yield (maize), and faba bean had 1.6-fold greater P uptake when intercropped with maize than in sole cropping, suggesting that niche differentiation led to each crop partner benefiting from different aspects of plasticity in terms of root placement and capacity for nutrient acquisition.
In another study, maize demonstrated root avoidance when grown with another maize plant, with reduced root growth in 'shared' soil (Zhang et al. 2020a). Conversely, maize roots proliferated and showed greater root overlap when grown with neighbouring faba bean plants (Zhang et al. 2020a). Maize shoot biomass was c. $30 \%$ larger and $\mathrm{P}$ content was $c .25 \%$ greater in the maize/faba bean combination than in the maize/maize system, which suggested that maize benefited from capturing the $\mathrm{P}$ mobilized by faba bean (from root citrate and acid phosphatase exudation) (Zhang et al. 2020a).

When maize and alfalfa were grown together, both crops showed more root proliferation in the topsoil than the monoculture crops, and roots proliferated laterally towards associated species and intermingled with each other (Sun et al. 2019). The intercropped species showed improved overall yield and P accumulation, but this was driven by alfalfa, which showed improved root growth (up to $60 \%$ increase in root dry mass), P uptake (by 1.5-fold) and yield (by twofold) in the intercrop compared to the monoculture. By contrast intercropped maize showed reduced root growth (30\% reduction in dry mass), phosphorus uptake (by 24\%), and yield (c. $10 \%$ reduction) (Sun et al. 2019). This might indicate that, for this intercrop pair, plasticity in root distribution was not sufficient to combat competition, and that overyielding was driven by selection effects favouring the dominant alfalfa.

The location of the different root systems in an intercrop seems to depend on the physical interactions between the component crops, but this might be modified by changing resource availability. Liu et al. (2015) found that the lateral spread of intercropped wheat roots decreased with increasing $\mathrm{N}$ application, while the maize component showed less morphological plasticity in spatial root distribution across different $\mathrm{N}$ application levels when intercropped; this plasticity correlated with crop differences in $\mathrm{N}$ uptake and biomass, which were increased in wheat and reduced in maize when intercropped, leading to overyielding compared with crop monocultures that might have resulted from selection effects (Liu et al. 2015). Moreover, Ma et al. (2019) showed that roots of wheat intercropped with maize spread further laterally under rainfed conditions than under supplementary irrigation, whereas the opposite was observed for maize. 
Root length density (RLD)

Increased root length in a soil volume is linked to improved soil exploration and resource capture. A study of root traits associated with enhanced $\mathrm{P}$ capture in diverse Steppe species mixtures on P-deficient soils showed the importance of root plasticity in realising facilitation benefits: although P-mobilising species such as Melissilus ruthenicus, Potentilla tanacetifolia and Filifolium sibiricum improved the availability of organic and inorganic phosphate in the soil, the non-mobilising species that showed improved biomass (Cleistogenes squarrosa and Bromus inermis) were those exhibiting plasticity in root length and, to a lesser extent, in the proportion of fine roots and root acid phosphatase activity (Yu et al. 2020). Different responses in RLD have been observed when plants are intercropped compared with monocultures. In a study of intercropped wheat and maize where root interactions were manipulated using a plastic film barrier, wheat roots that could interact with maize showed up to $70 \%$ increase in root length density down the soil profile compared with treatments where roots could not interact (Wang et al. 2018), although it varied between years. By contrast, intercropped maize exhibited reduced RLD at shallow depths and increased RLD deeper in the soil profile when roots were allowed to interact with neighbouring wheat plants. After wheat harvest, the intercropped maize showed accelerated root growth with highest root density achieved in the treatment where belowground root interaction had occurred, and this was thought to be responsible for $20 \%$ of the overall increase in grain yield resulting from intercropping (Wang et al. 2018).

By contrast, in a proso millet (Panicum miliaceum L.)/mung bean (Vigna radiata L.) intercrop system, both crops had a higher RLD in the upper $(0-50 \mathrm{~cm})$ soil layer and greater lateral spread when intercropped compared with the respective monoculture (Gong et al. 2020). This was linked with improved water uptake by intercropped proso millet, which benefited in terms of greater biomass and yield, whereas intercropped mung bean showed less productivity than monocropped plants, suggesting that the higher land use efficiency of the intercrop resulted from selection effects favouring proso millet dominance. A similar pattern was observed for intercropped maize and soybean, both of which displayed enhanced RLD compared with the corresponding monocrop (Ren et al. 2017), and this was associated with improved grain yield of maize but reduced soybean grain yield compared with their respective sole crops. Results from these two studies indicate that enhanced RLD by both intercropped partners might only lead to benefits through selection effects if one of the crops is dominant.

Furthermore, interspecific competition might even lead to reduced RLD of both crops, for example in tree-based alley cropping systems. The roots of intercropped walnut (Juglans regia) and wheat had smaller RLDs at all soil depths than those of sole walnut trees and wheat, and aboveground yield of each crop was reduced, although total yield showed that land use efficiency was improved in the intercrop (Zhang et al. 2015; Duan et al. 2019). Similarly, the roots of both intercropped cotton (Gossypium hirsutum) and jujube (Zizyphus jujuba) (Zhang et al. 2019b), and intercropped jujube and wheat (Zhang et al. 2013), had smaller RLDs compared with the respective monocultures. In these tree-based systems, yields of all component species were reduced when intercropped, but to a relatively small extent as land equivalent ratios were found to be greater than one, indicating more efficient overall use of resources under intercropping.

\section{Rooting depth}

Intercropping has been hypothesised to increase the rooting depth of crops and thus the soil volume and soil resources explored (Thorup-Kristensen et al. 2020). Plasticity in rooting depth could be beneficial in intercrop systems if it reduces direct root competition, allowing one plant species to access soil resources at depths that are inaccessible to the companion species. In a walnut/wheat agroforestry system, roots of the walnut trees grew significantly deeper compared with pure stands of walnut trees (Cardinael et al. 2015). There were twice as many fine walnut roots in the top $50 \mathrm{~cm}$ of soil in the tree monocrop than when intercropped, but intercropped trees grew fine roots to much greater depths compared to the monocrop (i.e. below the depth reached by the annual crop roots). This plasticity reduced direct root competition with the wheat crop, enabling trees to access deeper water tables not available to wheat roots. By contrast, Neykova et al. (2011) 
found no consistent differences in the rooting depth down to $1.4 \mathrm{~m}$ between single-crop and intercropping systems of maize and legumes. However, more even vertical distribution of fine roots down the soil profile was observed in the intercropping systems compared to the monocrops. These studies did not, however, examine how these rooting depth changes affected water or nutrient uptake and yield.

\section{Average root diameter}

A root system is composed of a heterogeneous assembly of roots of different diameters. Roots with a relatively large diameter are involved in storage of plant resources and the transport of water and nutrients, whereas fine roots are responsible for the absorption of soil resources (Zadworny et al. 2016). A shift in the average diameter of the root system could indicate a change in the root system's overall nutrient uptake capacity; a smaller average root diameter might signify a larger fraction of absorptive roots. In a walnut/wheat intercrop system, the root diameter of both component species was smaller than that of sole walnut trees and wheat (Zhang et al. 2015). Despite a smaller average root diameter, root competition belowground in the intercrop system led to decreases in yield and biomass of both crops. Similarly, the roots of intercropped cotton and jujube both had smaller root diameters at all soil depths compared with those of sole-cropped cotton and jujube trees (Zhang et al. 2019b) and cotton and the jujube fruit yields were reduced, although land use efficiency was improved.

By contrast, intercropping poplar (Populus alba L.) with alfalfa reduced the average root diameter (and yield) of alfalfa and increased the average root diameter of poplar in the top soil layers, but with no effect on stem wood volume (Yang et al. 2019). Intercropping millet with peanut (Arachis hypogaea) was associated with smaller average millet root diameter, but no significant change in peanut root diameter, when roots were allowed to interact belowground (Zou et al. 2019). There was, however, a 50-60\% increase in root volume of both species and more than two-fold increase in biomass yield (of each crop and the intercrop) compared with an intercrop treatment where root interaction was prevented with a solid barrier, accompanied by similar increases in $\mathrm{N}, \mathrm{P}$ and $\mathrm{K}$ acquisition (Zou et al. 2019).
Fine roots and root hairs

Despite their small size, fine roots (diameter $<2 \mathrm{~mm}$ ) are considered the most active in taking up soil resources. Fine roots can grow into smaller soil pores, increasing root contact with the soil solution, and root surface area for water and nutrient uptake (Volder and van Iersel 2019). Root hairs, which are extensions of root epidermal cells, further increase the absorptive surface area of the root (Zhu et al. 2010).

In tree-based alley cropping systems, the fine roots of the intercropped trees seem to extend into deeper soil layers, while the fine roots of the intercropped annual crops remain in shallower soil compared with the respective monocultures: this was the case for apple (Malus pumila M.) intercropped with either soybean or peanut (Sun et al. 2018). Apple-annual crop intercropping inhibited growth of the fine roots of apple trees in the $0-60 \mathrm{~cm}$ soil depth, reducing fine root density by $25-35 \%$, while fine root density in the $60-100 \mathrm{~cm}$ soil layer was unchanged compared to the monoculture; by contrast, fine root density of the intercropped soybean or peanut was reduced throughout the soil profile (Sun et al. 2018). In a study of annual crops, the fine roots of maize intercropped with several legumes were found to be more homogeneously distributed down the soil profile than in the maize monoculture, with $50 \%$ of fine roots located in the $0-36 \mathrm{~cm}$ soil layer in the intercrop and in the 15-21 cm soil depth in monocultures (Neykova et al. 2011). Furthermore, artichoke (Cynara cardunculus L.) grown with living mulch showed proliferation of root hairs, which was not observed in artichoke grown alone (Trinchera et al. 2017). Additionally, living mulch promoted root mycorrhizal colonisation (up to three-fold depending on artichoke cultivar) which improved $\mathrm{P}$ depletion of the rhizosphere. However, living mulch had no effect on the yield of intercropped artichoke, when compared with the sole crop.

Root nutrient uptake capacity and nutrient transport ability

One of the most important physiological functions of roots is the uptake of water and nutrients, which can vary along the length of the root and with root anatomy. Intercropped plants might increase nutrient uptake capacity by increasing the number of 
absorptive roots or density of root hairs, or through the physiological adjustment of resource uptake kinetics. A common observation in intercropped systems is when one component crop increases nutrient uptake, while the other crop shows no change or reduced uptake. During the co-growth period of wheat intercropped with maize, wheat showed two-to-fourfold higher $\mathrm{N}$ uptake rates per unit root length compared with the sole crop, while that of intercropped maize was reduced by c. $25-50 \%$ relative to the sole crop (Liu et al. 2015). After wheat harvest, intercropped maize can 'recover' as shown in a further study where the $\mathrm{N}$ uptake per unit root length was two-fold greater than for sole cropped maize (Liu et al. 2020b). In parallel, the intercropped wheat in these two studies accumulated 25-30\% more aboveground biomass and grain yield than sole cropped wheat, while maize yield was not affected by intercropping, resulting in higher yield from the intercrop (Liu et al. 2020a, b). Similar results were observed by Li et al. (2001b) in a wheat/soybean and wheat/maize system: compared with sole crops, the $\mathrm{N}$ and $\mathrm{P}$ accumulation rates of intercropped soybean and intercropped maize were impaired at the early growth stage, but then recovered after wheat harvest to reach higher levels than sole crop stands which led to up to two-fold higher biomass accumulation compared with soybean and maize sole crops (Li et al. 2001b).

The mechanisms underpinning improved nutrient uptake, such as changes in membrane transporter activity, have been investigated in only a few cases. In a millet/peanut intercrop system, $\mathrm{N}$ and $\mathrm{P}$ acquisition by millet increased as a result of upregulated expression of proteins involved in $\mathrm{N}$ and $\mathrm{P}$ transport, such as urease (which releases inorganic $\mathrm{N}$ from urea: de Souza et al. 2020) and the transmembrane inorganic phosphate transporter $1-4$, while peanut roots showed elevated expression of malate dehydrogenase (Zou et al. 2019). Expression of P transporter genes in maize can be induced by phosphate-starvation (Nagy et al. 2006): when intercropped with faba bean, the expression levels of these transporter genes was downregulated by $30-70 \%$ in maize roots, indicating that intercropping had enhanced soil $\mathrm{P}$ availability and thus improved the $\mathrm{P}$ status of maize, as shown by the parallel increase in maize shoot $\mathrm{P}$ content (Yan et al. 2014). However, increases in membrane transport activity might have little effect on the ability of roots to acquire immobile nutrients if these are not present in the soil surrounding the roots. For instance, genes encoding $\mathrm{P}$ transporters might be induced, but, unless phosphate is available for uptake from the soil solution, the increased transporter activity will have little consequence.

Root exudation of phosphatases or carboxylates

In intercropped peanut/maize, the activity of acid phosphatases in the rhizosphere and bulk soil, and in root secretions, was $30-90 \%$ higher relative to monoculture peanut and maize (Inal et al. 2007). This led to 2-2.5-fold higher tissue concentrations of $\mathrm{Fe}$ and $\mathrm{Zn}$ in peanut and 0.2-to-twofold higher tissue $\mathrm{P}$ and $\mathrm{K}$ concentrations in peanut and maize; tissue $\mathrm{N}$ concentrations were unchanged by intercropping. Despite higher tissue nutrient concentrations of the intercropped plants, shoot dry weights of both peanut and maize were significantly smaller (by 20-30\%) when intercropped compared with those in the corresponding monocultures, suggesting that total nutrient uptake was reduced, and that increased acid phosphatase activity did not directly benefit either species when intercropped. Similarly, maize intercropped with faba bean showed no change in shoot or root biomass or plant $\mathrm{P}$ content despite a 12-fold increase in rhizosphere concentrations of malate in the intercrop compared with maize monoculture (Li et al. 2013). Faba bean, however, benefited from being intercropped with maize, showing 10-15\% increases in shoot biomass and $\mathrm{P}$ content compared with monocropped faba bean ( $\mathrm{Li}$ et al. 2013), possibly due to reduced within-species competition (i.e. through niche differentiation) for soil $\mathrm{P}$ released by exuded malate.

Root interactions between rapeseed (Brassica napus) and Chinese milk vetch (Astragalus sinicus) facilitated P uptake (c. 30\% increase) and root growth (c. $25 \%$ increase) in rapeseed grown with three plants of Chinese milk vetch (Zhang et al. 2019a). Citrate and phosphatase exudation in the rhizosphere of Chinese milk vetch increased 0.5-to-sixfold when grown with rapeseed compared with the monocrop, with highest values achieved when vetch planting densities were reduced from 15 to 6 plants per rapeseed plant (Zhang et al. 2019a). However, even with these positive rhizosphere interactions the intercropping systems still produced similar or less biomass compared with the monoculture. 
Mycorrhizal fungi

Various studies have reported that intercropping systems inoculated with arbuscular mycorrhizal fungi performed better (increased biomass) than corresponding monocultures and non-mycorrhizal intercrops due to increased nutrient and water uptake (Ren et al. 2013; Wahbi et al. 2016; Singh et al. 2019) and alleviated disease (Ren et al. 2008). Mycorrhizae seem to benefit from the increased plant diversity under intercropping, due to a larger number of possible host-fungal pairings and increased amount of plant roots available for colonization (Burrows and Pfleger 2002). In a mixed cropping system of two cutflower species, mixed cropped plants had significantly higher (20-70\%) mycorrhizal colonization than the corresponding monocropped plants (Riaz and Javaid 2017), although there was no overall effect on flower and bulb yields. Introduction of trees into agricultural crops to create alley crops has been shown to promotes the diversity of mycorrhizal fungi and abundance of fungal spores compared with forest monocrops (Chifflot et al. 2009; Lacombe et al. 2009). These effects, however, are not consistent between sites and tree species (Lacombe et al. 2009; Bainard et al. 2011a), with some studies showing neutral or negative effects, and the functional consequences of these changes remains to be established (Bainard et al. 2011b).

\section{Selecting root traits to improve intercrop performance}

A major challenge when supporting the development of intercropping systems remains the design of suitable mixtures of species or cultivars. Choice of crop species combinations and intercrop sowing patterns can be altered to optimise complementarity effects and reduce selection effects (Li et al. 2020b). Modern crop varieties are not necessarily the most suitable for optimising complementarity effects in intercrop systems, as they have been bred for monocultures, typically with high input levels, and plant traits considered beneficial in these conditions may not be ideal for intercropping (Lithourgidis et al. 2011). However, crop breeding programs for intercrops are rare and a clear definition of which root ideotypes plant breeders should consider for positive interactions, such as niche differentiation and facilitation, is lacking. Here we propose a set of root traits that could optimise these beneficial plant-plant interactions and improve intercrop performance.

\section{Complementarity in root traits}

A first step involves identifying the intended outcome of plant team cropping, whether to optimise yield or grain quality, resource use efficiency, or pest suppression, and characterising the complementary traits in the plant team partners likely to underpin these outcomes (Table 1). Desirable traits need to be selected in concert for the component crops (Table 1) to focus on characteristics that promote facilitation, complement each other in terms of resource requirements in space and time, and minimise crop-crop competition (Louarn et al. 2020). As discussed in the previous section, plasticity in belowground traits is likely to play a key role in improving intercrop performance relative to monocultures. Morphological root plasticity can enhance niche differentiation (Table 1), for example through vertical separation, whereby one crop grows its roots in upper layers and the other crops grows its root in deeper soil layers below its neighbour, thereby reducing competition for resources in the same soil stratum ( $\mathrm{Li}$ et al. 2006; Streit et al. 2019). Moreover, this plasticity can also favour facilitation (Table 1), when plants grow towards neighbouring plants, leading to root intermingling, thereby facilitating nutrient uptake (Sun et al. 2019; Zhang et al. 2020a). Despite being a potentially beneficial trait for intercrops, there are challenges in determining if morphological root plasticity is heritable and whether this trait could be implemented to provide consistent benefits in terms of overyielding (Table 1).

Another interesting root trait target for breeding for niche differentiation could be the ability to shift preference for nitrate $\left(\mathrm{NO}_{3}{ }^{-}\right)$to ammonium $\left(\mathrm{NH}_{4}{ }^{+}\right)$or vice versa (Table 1). Adjusting $\mathrm{N}$ uptake strategy could be beneficial for differentiating the uptake of chemical $\mathrm{N}$ forms by intercropped plants. As described above, Liu et al. (2020a) studied the N uptake pattern of two grasses growing together and found that one of the two grasses was more capable of changing its $\mathrm{N}$ uptake strategy. Furthermore, Ashton et al. (2010) studied four alpine species, and showed that they shifted their $\mathrm{N}$ uptake strategy when grown with a neighbour, compared with being grown alone. 
They also found that the dominant species increased uptake of the main $\mathrm{N}$ form $\left(\mathrm{NH}_{4}^{+}\right)$by 3-to-eightfold when interacting with other species, but the competitively inferior species showed no adjustment in $\mathrm{N}$ uptake strategy. Similarly, different plants can regulate $\mathrm{P}$ uptake through expression of phosphate transporters and therefore expression of these transporters at different times and locations on the root system could lead to complementarity between crops.

Table 1 Root trait ideotypes for mixed cropping that could lead to niche differentiation and/or facilitation and might benefit intercrop plant functions. References highlighted in green represent studies where there was clear overyielding of the intercropped system, while text in red shows where intercropped systems underyielded compared to sole crops. Stud-
In the case of facilitation, the root traits of the 'facilitator' seem to be of most importance. Plants exuding particular root exudate compounds could improve phosphorus uptake or the suppression of soil borne pathogens in the partner crop without apparent direct benefit to the facilitator species (Table 1). Facilitation can also occur between plants that are linked by mycorrhizal hyphal networks, which may allow transfer of resources from

ies with amber text either showed no effect of intercropping on yield or had mixed effects when comparing either different partner crops or times within the growing season. Where text is black there was no evidence provided in the study of impact on yield

\begin{tabular}{|c|c|c|c|c|c|c|}
\hline Root trait & Niche differentiation & Example & Facilitation & Example & $\begin{array}{l}\text { Intercrop } \\
\text { patterns }\end{array}$ & References \\
\hline $\begin{array}{l}\text { Plasticity in } \\
\text { root } \\
\text { distribution }\end{array}$ & $\begin{array}{l}\text { Vertical separation of } \\
\text { roots to access discrete } \\
\text { soil resources }\end{array}$ & $\begin{array}{l}\text { Crop 1: Root growth into } \\
\text { deeper soil layer under } \\
\text { component crop } \\
\text { Crop 2: Root proliferation } \\
\text { in the upper soil layers }\end{array}$ & $\begin{array}{l}\text { Root proliferation } \\
\text { towards neighbouring } \\
\text { species and root } \\
\text { intermingling }\end{array}$ & $\begin{array}{l}\text { Growth towards P- } \\
\text { mobilizing species } \\
\text { roots, to capture } \\
\text { mobilized P }\end{array}$ & $\begin{array}{l}\text { Mixed } \\
\text { Row } \\
\text { Relay } \\
\text { Agroforestry }\end{array}$ & $\begin{array}{l}\text { (Zhang et al. } \\
\text { 2020a) } \\
\text { (Streit et al. 2019) } \\
\text { (Li et al. 2006) } \\
\text { (Cardinael et al. } \\
\text { 2015) } \\
\text { (Sun et al. 2019) } \\
\text { Yu et al. (2020) }\end{array}$ \\
\hline $\begin{array}{l}\text { Fine roots } \\
\text { and root } \\
\text { hairs }\end{array}$ & $\begin{array}{l}\text { Vertical separation of fine } \\
\text { root placement }\end{array}$ & $\begin{array}{l}\text { Crop 1: Fine roots of } \\
\text { intercropped trees extend } \\
\text { into deeper soil layers } \\
\text { Crop 2: Fine roots of } \\
\text { intercropped annual crops } \\
\text { remain in shallower soil }\end{array}$ & $\begin{array}{l}\text { Increased fine root } \\
\text { density and proliferation } \\
\text { of root hairs to capture } \\
\text { resources when } \\
\text { intercropped }\end{array}$ & $\begin{array}{l}\text { Increased absorptive } \\
\text { surface area of the } \\
\text { root system could } \\
\text { enhance water and } \\
\text { nutrient uptake }\end{array}$ & $\begin{array}{l}\text { Mixed } \\
\text { Agroforestry }\end{array}$ & $\begin{array}{l}\text { (Sun et al. 2018) } \\
\text { (Neykova et al. } \\
\text { 2011) } \\
\text { (Trinchera et al. } \\
\text { 2017) } \\
\text { (Wang et al. 2018) }\end{array}$ \\
\hline $\begin{array}{l}\text { Nutrient } \\
\text { uptake } \\
\text { capacity }\end{array}$ & $\begin{array}{l}\text { Upregulated activity of } \\
\text { transporters involved in } \mathrm{N} \\
\text { and } \mathrm{P} \text { transportation }\end{array}$ & $\begin{array}{l}\text { Crop 1: Improved nutrient } \\
\text { uptake during co-growth } \\
\text { period (at the expense of } \\
\text { component crop) } \\
\text { Crop 2: Enhanced } \\
\text { nutrient uptake per unit } \\
\text { root length, after harvest } \\
\text { of component crop }\end{array}$ & & & $\begin{array}{l}\text { Mixed } \\
\text { Relay }\end{array}$ & $\begin{array}{l}\text { (Liu et al. 2015) } \\
\text { (Liu et al. 2020a) } \\
\text { (Liu et al. 2020b) } \\
\text { (Li et al. 2001b) }\end{array}$ \\
\hline $\begin{array}{l}\text { Plasticity in } \\
\text { nutrient } \\
\text { uptake form }\end{array}$ & $\begin{array}{l}\text { Increased uptake of one } \\
\text { form of } \mathrm{N} \text { over another } \\
\left(\mathrm{NO}_{3}^{-} \text {vs. } \mathrm{NH}_{4}^{+}\right)\end{array}$ & $\begin{array}{l}\text { Crop 1: Increased uptake } \\
\text { of their main } \mathrm{N} \text { form } \\
\left(\mathrm{NO}_{3}^{-}\right) \\
\text {Crop 2: Reduced } \mathrm{NO}_{3}^{-} \\
\text {uptake, enhanced } \mathrm{NH}_{4}{ }^{-} \\
\text {uptake }\end{array}$ & & & $\begin{array}{l}\text { Mixed } \\
\text { Row }\end{array}$ & $\begin{array}{l}\text { (Liu et al. 2020a) } \\
\text { (Ashton et al. } \\
2010 \text { ) }\end{array}$ \\
\hline $\begin{array}{l}\text { Exudation of } \\
\text { phosphatases } \\
\text { or } \\
\text { carboxylates }\end{array}$ & $\begin{array}{l}\text { Utilisation of more } \\
\text { recalcitrant forms of } \mathrm{P} \\
\text { leaving available } \mathrm{P} \text { for co- } \\
\text { crop }\end{array}$ & $\begin{array}{l}\text { Crop 1: Increased use of } \\
\text { organic P } \\
\text { Crop 2: Greater access to } \\
\text { soil available P }\end{array}$ & $\begin{array}{l}\text { Increased acid } \\
\text { phosphatase activity or } \\
\text { increased citrate or } \\
\text { malate secretion in } \\
\text { intercrop systems }\end{array}$ & $\begin{array}{l}\text { Mobilise soil organic } \\
\text { phosphorus and } \\
\text { increase soluble } \\
\text { inorganic phosphorus } \\
\text { availability for one or } \\
\text { both crops }\end{array}$ & $\begin{array}{l}\text { Mixed } \\
\text { Row }\end{array}$ & $\begin{array}{l}\text { (Inal et al. 2007) } \\
\text { (Zou et al. 2019) } \\
\text { (Zhang et al. } \\
\text { 2019a) } \\
\text { (Li et al. 2013) } \\
\text { (Yu et al. (2020) }\end{array}$ \\
\hline $\begin{array}{l}\text { Toxic or } \\
\text { deterrent } \\
\text { root exudates }\end{array}$ & & & $\begin{array}{l}\text { Exudation of } \\
\text { antimicrobial } \\
\text { compounds }\end{array}$ & $\begin{array}{l}\text { Suppression of soil- } \\
\text { borne pathogens of } \\
\text { neighbouring crops }\end{array}$ & $\begin{array}{l}\text { Mixed } \\
\text { Row }\end{array}$ & $\begin{array}{l}\text { (Zhou et al. 2019) } \\
\text { (Hao et al. 2010) } \\
\text { (Gao et al. 2014) } \\
\text { (Kong et al. 2004) }\end{array}$ \\
\hline $\begin{array}{l}\text { Mycorrhizal } \\
\text { fungi }\end{array}$ & $\begin{array}{l}\text { Utilisation of physically } \\
\text { discrete resources }\end{array}$ & $\begin{array}{l}\text { Crop 1: Increased use of } \\
\text { nutrients in small soil } \\
\text { pores } \\
\text { Crop 2: Greater access to } \\
\text { root available nutrients }\end{array}$ & $\begin{array}{l}\text { Increased mycorrhizal } \\
\text { fungal diversity, } \\
\text { abundance and root } \\
\text { colonisation in intercrop } \\
\text { systems }\end{array}$ & $\begin{array}{l}\text { Transfer of soil } \\
\text { resources between } \\
\text { plants through } \\
\text { mycorrhizal networks }\end{array}$ & $\begin{array}{l}\text { Mixed } \\
\text { Row } \\
\text { Strip } \\
\text { Relay } \\
\text { Agroforestry }\end{array}$ & $\begin{array}{l}\text { (Riaz and Javaid } \\
\text { 2017) } \\
\text { (Bainard et al. } \\
\text { 2011a) } \\
\text { (Ren et al. 2013) } \\
\text { (Singh et al. 2019) }\end{array}$ \\
\hline
\end{tabular}


one plant to another. The ability to use distinct pools of nutrients in soil either through exudates which give access to a specific form of $\mathrm{P}$ (e.g. phosphatase and organic P) or through access to physically occluded sources of nutrients (e.g. through association with mycorrhizae that increase the volume of soil explored) can also allow the partner plants to be complementary to one another allowing access to discrete resources from the same soil volume. Nevertheless, many of these traits are unlikely to work in isolation: for example, intercropping a P-mobilizing species with a partner plant that can respond by increasing $\mathrm{P}$ uptake transporter activity or altering its root distribution to be in closer proximity to its neighbour would be most beneficial. This makes for a complex genetic improvement programme, where multiple traits need to be targeted in multiple crop species to give the optimal combination of root traits in the resultant intercrop.

\section{Root traits and selection effects}

High yields in intercrops, in some cases, might simply result from the mixture being dominated by a highyielding species (i.e. positive selection effects), particularly when productivity is promoted by large fertiliser inputs. A study of maize-legume intercrops in China showed that the net biodiversity effect on intercrop yield was explained largely by complementarity effects in the absence of nitrogen fertiliser but shifted towards selection effects when nitrogen fertiliser was applied (Zhang et al. 2021). Positive selection effects mean that species mixtures will outperform the average monoculture, but not the best monoculture, whereas complementarity effects promote the overall performance of species in mixtures and lead to greater net resource use (Schöb et al. 2015). Although complementarity effects are likely to be more desirable for intercrop improvement, not least because they have the potential to reduce fertiliser use, it is useful to consider the plant traits that might underpin selection effects.

Amongst arable weed species, positive selection effects were associated with rapid growth and large biomass (Schöb et al. 2015). By analogy, it can be speculated that root traits contributing to positive selection effects in intercrops are also likely to be those associated with greater crop productivity - often a key target for modern crop breeding — suggesting that root traits selected during the process of developing modern cultivars for monoculture cropping might also underpin positive selection effects in intercrops. Crop breeding and selection over many decades and centuries have successfully created domesticated crop varieties with larger biomass and harvest index, and these characteristics are associated with increased root biomass compared with wild progenitor species (Martín-Robles et al. 2019). The root traits underpinning greater root biomass in domesticated crops vary in importance, however, and can be achieved through individual or combined traits including larger root density, thickness, and length (Martín-Robles et al. 2019). Crop improvement in wheat over $>100$ years, for example, has increased yield and harvest index, and simplified the root system, with modern varieties exhibiting fewer longer seminal roots exhibiting smaller lateral spread than older cultivars (Zhu et al. 2019).

The possibility that root traits leading to greater productivity are also those that underpin positive selection effects is borne out by some studies highlighted in this review. For example, high yields in intercrops of maize-alfalfa (Sun et al. 2019) and millet-mung bean (Gong et al. 2020) were driven by better performance of one component (alfalfa and millet, respectively) and these dominant species showed larger root mass, increased root proliferation in the topsoil and greater lateral root spread. If root trait choice for positive selection effects can be guided by the breeding targets of faster biomass accumulation and rapid resource capture (i.e. root vigour), then rapid root emergence and a genetic predisposition for rooting depth that matches local soil water and nutrient availabilities are proposed as traits of focus for future 'designer crops', along with the ability for plastic root growth in response to resource deficiencies (Voss-Fels et al. 2018). Indeed, a study of wheat-maize intercrops highlighted in this review lends support to these suggestions, revealing that wheat showed greater plasticity in lateral root spread than maize (in response to increasing $\mathrm{N}$ availability), and wheat intercropped with maize achieved higher yields compared to wheat monocultures while intercropped maize yields were reduced (Liu et al. 2015). Future targets for crop improvement could be guided by existing knowledge of root traits correlated with early vigour, such as root length (in cotton: Liu et al. 2019; and in wheat: Vijaya Bhaskar et al. 2019). 
Agronomy to maximise intercrop root trait effects

Alongside identifying root traits that could be used in designing crop combinations suited to intercropping, the sowing ratio of component crops, and their spatio-temporal arrangement in the field, are important considerations. Intercropping outcomes can differ greatly between crop combinations and might be influenced further by agronomic choices that alter the behaviour of roots, meaning that even dramatic changes in expression of complementary root traits might not always translate into benefits for intercrop performance. For instance, the distance between the intercropped plants influences the extent of root intermingling, which is essential for facilitating $\mathrm{P}$ uptake between plants with different $\mathrm{P}$ uptake strategies (Giles et al. 2018). Moreover, in two years of field experiments, maize/soybean intercropping suppressed the occurrence of soybean red crown rot by 30 to $50 \%$, and this reduction was much greater with decreasing distance between plants (Gao et al. 2014). With only a handful of examples for each root trait and a range of external factors influencing the behaviour of roots, further research is necessary to characterise optimal sowing patterns, plant combinations and densities for different crop mixtures and root trait combinations.

The different mechanisms at play between intercropped roots are also likely to vary between types of intercropping systems. For instance, in relay intercropping, the ability of the late planted crop to rapidly increase root growth (e.g. root length density) and nutrient uptake after the dominant crop has been harvested seems to underpin the success of these types of intercrop systems. These temporal changes in root traits are probably less important for intercropping systems where plants are grown simultaneously throughout their growing period. Plasticity in rooting depth might be less important in tree-based intercrop systems, as trees usually grow their roots in deeper soil layers than the intercropped annual crops. However, more information is needed regarding how intercrop management, such as sowing patterns, planting densities and ratios, timing of planting and harvesting, and preceding crops in the rotation, influence root behaviour in intercrops. Furthermore, understanding root behaviour in response to environmental factors, such as variation in water and nutrient availability, soil type, soil microbiome composition and the presence of other belowground organisms, remains fragmented. It is hoped that this synthesis of current knowledge will stimulate further research to fill these knowledge gaps and address important questions surrounding the nature of root-root interactions in intercrop systems and the root traits that influence their outcomes.

\section{Conclusion}

Intercropping has been used as a viable agricultural practice for thousands of years and is widespread in many parts of the world, but there are still major knowledge gaps in understanding the mechanisms of interactions between intercropped roots, the root traits that influence those mechanisms and the importance of trait plasticity. Synthesis of the existing literature has highlighted root trait combinations or intercrop 'ideotypes' that might promote complementarity between species, and indicates that spatial and temporal trait plasticity could vary in importance for mixed, relay and agroforestry intercrops. Better understanding of intercropping systems could help increase the implementation of these systems in modern agriculture. We need to assess belowground interactions as critically as aboveground processes and consider both spatial distribution of roots and mechanisms in the rhizosphere that aid complementarity and reduce competition. If it is soundly practiced, intercrops use soil resources more efficiently and require fewer fertilizer and pesticide inputs. Intercropping can therefore be a sustainable, low-input method of farming with potential to provide resilience in a future with uncertain climatic conditions. Filling the existing knowledge gaps regarding important traits for intercropped species and varieties, and enabling farmers to adopt intercropping practices, are essential next steps for a fruitful future for intercropping.

Acknowledgements We thank the reviewers for constructive feedback on this manuscript, which has improved the clarity and potential impact of the review. This work was conducted as part of a Master's thesis for the double-degree Agroecology MSc programme under supervision of Florian Celette and Tor Arvid Breland at ISARA-Lyon and NMBU, respectively. The contribution of James Hutton Institute staff was supported by the Rural \& Environment Science \& Analytical Services Division of the Scottish Government and by the DIVERSify project funded by the European Union's Horizon 2020 research 
and innovation programme under grant agreement No. 727284 . We thank Prof. Philip White at the James Hutton Institute for insightful comments on the manuscript.

Open Access This article is licensed under a Creative Commons Attribution 4.0 International License, which permits use, sharing, adaptation, distribution and reproduction in any medium or format, as long as you give appropriate credit to the original author(s) and the source, provide a link to the Creative Commons licence, and indicate if changes were made. The images or other third party material in this article are included in the article's Creative Commons licence, unless indicated otherwise in a credit line to the material. If material is not included in the article's Creative Commons licence and your intended use is not permitted by statutory regulation or exceeds the permitted use, you will need to obtain permission directly from the copyright holder. To view a copy of this licence, visit http://creativecommons.org/licenses/by/4.0/.

\section{References}

Agegnehu G, Ghizaw A, Sinebo W (2008) Yield potential and land-use efficiency of wheat and faba bean mixed intercropping. Agron Sustain Dev 28:257-263. https://doi. org/10.1051/agro:2008012

Ashton IW, Miller AE, Bowman WD, Suding KN (2010) Niche complementarity due to plasticity in resource use: plant partitioning of chemical $\mathrm{N}$ forms. Ecology 91:3252-3260. https://doi.org/10.1890/09-1849.1

Bainard LD, Koch AM, Gordon AM, Newmaster SG, Thevathasan NV, Kliromonos JN (2011a) Influence of trees on the spatial structure of arbuscular mycorrhizal communities in a temperate tree-based intercropping system. Agric Ecosyst Environ 144:13-20. https://doi.org/10. 1016/j.agee.2011.07.014

Bainard LD, Klironomos JN, Gordon AM (2011b) Arbuscular mycorrhizal fungi in tree-based intercropping systems: a review of their abundance and diversity. Pedobiologia 54:57-61. https://doi.org/10.1016/j.pedobi.2010.11.001

Bedoussac L, Journet E-P, Hauggaard-Nielsen H, et al (2018) Grain legume-cereal intercropping systems. In: Achieving sustainable cultivation of grain legumes. Burleigh Dodds Science Publishing Limited

Björkman M, Hambäck PA, Rämert B (2007) Neighbouring monocultures enhance the effect of intercropping on the turnip root fly (Delia floralis). Entomol Exp Appl 124:319-326. https://doi.org/10.1111/j.1570-7458.2007. 00589.x

Björkman M, Hopkins RJ, Rämert B (2008) Combined effect of intercropping and turnip root fly (Delia floralis) larval feeding on the glucosinolate concentrations in cabbage roots and foliage. J Chem Ecol 34:1368. https://doi.org/ 10.1007/s10886-008-9533-0

Björkman M, Hopkins RJ, Hambäck PA, Rämert B (2009) Effects of plant competition and herbivore density on the development of the turnip root fly (Delia floralis) in an intercropping system. Arthropod-Plant Interact 3:55-62. https://doi.org/10.1007/s11829-009-9055-X
Boudreau MA (2013) Diseases in intercropping systems. Annu Rev Phytopathol 51:499-519. https://doi.org/10.1146/ annurev-phyto-082712-102246

Boudsocq S, Niboyet A, Lata JC et al (2012) Plant preference for ammonium versus nitrate: a neglected determinant of ecosystem functioning? Am Nat 180:60-69. https://doi. org/10.1086/665997

Britto DT, Kronzucker HJ (2013) Ecological significance and complexity of $\mathrm{N}$-source preference in plants. Ann Bot 112:957-963. https://doi.org/10.1093/aob/mct157

Brooker RW, Bennett AE, Cong W-F et al (2015) Improving intercropping: a synthesis of research in agronomy, plant physiology and ecology. New Phytol 206:107-117. https://doi.org/10.1111/nph.13132

Brooker R, George T, Homulle Z et al (2021) Facilitation and biodiversity ecosystem function (BEF) relationships in crop production systems and their role in sustainable farming. J Ecol 109(5):2054-2067. https://doi.org/10. $1111 / 1365-2745.13592$

Burrows RL, Pfleger FL (2002) Arbuscular mycorrhizal fungi respond to increasing plant diversity. Can J Bot 80:120 130. https://doi.org/10.1139/b01-138

Cardinael R, Mao Z, Prieto I et al (2015) Competition with winter crops induces deeper rooting of walnut trees in a Mediterranean alley cropping agroforestry system. Plant Soil 391:219-235. https://doi.org/10.1007/ s11104-015-2422-8

Chapagain T, Riseman A (2014) Barley-pea intercropping: effects on land productivity, carbon and nitrogen transformations. Field Crops Res 166:18-25. https://doi.org/ 10.1016/j.fcr.2014.06.014

Chen BJW, Xu C, Liu M-S et al (2020) Neighbourhooddependent root distributions and the consequences on root separation in arid ecosystems. J Ecol. https://doi.org/ 10.1111/1365-2745.13360

Chifflot V, Rivest D, Olivier A et al (2009) Molecular analysis of arbuscular mycorrhizal community structure and spores distribution in tree-based intercropping and forest systems. Agric Ecosyst Environ 131:32-39. https://doi. org/10.1016/j.agee.2008.11.010

Cong W-F, Hoffland E, Li L et al (2015) Intercropping enhances soil carbon and nitrogen. Glob Change Biol 21:1715-1726. https://doi.org/10.1111/gcb.12738

Corre-Hellou G, Fustec J, Crozat Y (2006) Interspecific competition for soil $\mathrm{N}$ and its interaction with $\mathrm{N} 2$ fixation, leaf expansion and crop growth in pea-barley intercrops. Plant Soil 282:195-208. https://doi.org/10.1007/ s11104-005-5777-4

Cu STT, Hutson J, Schuller KA (2005) Mixed culture of wheat (Triticum aestivum L.) with white lupin (Lupinus albus L.) improves the growth and phosphorus nutrition of the wheat. Plant Soil 272:143-151. https://doi.org/10.1007/ s11104-004-4336-8

Dai C-C, Chen Y, Wang X-X, Li P-D (2013) Effects of intercropping of peanut with the medicinal plant Atractylodes lancea on soil microecology and peanut yield in subtropical China. Agrofor Syst 87:417-426. https://doi.org/10. 1007/s10457-012-9563-z 
Dawson TE (1993) Hydraulic lift and water use by plants: implications for water balance, performance and plantplant interactions. Oecologia 95:565-574. https://doi.org/ 10.1007/BF00317442

de Medeiros EV, de Notaro K, A, Barros JA de, et al (2019) Soils from intercropped fields have a higher capacity to suppress black root rot in cassava, caused by Scytalidium lignicola. J Phytopathol 167:209-217. https://doi.org/10. 1111/jph.12788

de Souza SCR, Sodek L, Polacco JC, Mazzafera P (2020) Urease deficiency alters nitrogen metabolism and gene expression in urease-null soybean without affecting growth or productivity under nitrate supply. Acta Physiol Plant 42:34. https://doi.org/10.1007/s11738-020-3020-9

Duan ZP, Gan YW, Wang BJ et al (2019) Interspecific interaction alters root morphology in young walnut/wheat agroforestry systems in northwest China. Agrofor Syst 93:419-434. https://doi.org/10.1007/s10457-017-0133-2

Duchene O, Vian J-F, Celette F (2017) Intercropping with legume for agroecological cropping systems: Complementarity and facilitation processes and the importance of soil microorganisms. A Review Agric Ecosyst Environ 240:148-161. https://doi.org/10.1016/j.agee.2017.02.019

Ehrmann J, Ritz K (2014) Plant: soil interactions in temperate multi-cropping production systems. Plant Soil 376:1-29. https://doi.org/10.1007/s11104-013-1921-8

El-Hamawi MH, Youssef MMA, Zawam HS (2004) Management of Meloidogyne incognita, the root-knot nematode, on soybean as affected by marigold and sea ambrosia (damsisa) plants. J Pest Sci 77:95-98. https:// doi.org/10.1007/s10340-003-0034-1

Faget M, Nagel KA, Walter A et al (2013) Root-root interactions: extending our perspective to be more inclusive of the range of theories in ecology and agriculture using in-vivo analyses. Ann Bot 112:253-266. https://doi. org/10.1093/aob/mcs296

Fan F, Zhang F, Song Y et al (2006) Nitrogen fixation of faba bean (Vicia faba L.) interacting with a non-legume in two contrasting intercropping systems. Plant Soil 283:275286. https://doi.org/10.1007/s11104-006-0019-y

Frankow-Lindberg BE, Dahlin AS (2013) N2 fixation, N transfer, and yield in grassland communities including a deep-rooted legume or non-legume species. Plant Soil 370:567-581. https://doi.org/10.1007/ s11104-013-1650-z

Fukai S, Trenbath BR (1993) Processes determining intercrop productivity and yields of component crops. Field Crops Res 34:247-271. https://doi.org/10.1016/0378-4290(93) 90117-6

Gao X, Wu M, Xu R, et al (2014) Root Interactions in a maize/ soybean intercropping system control soybean soil-borne disease, red crown rot. PLoS ONE. https://doi.org/10. 1371/journal.pone.0095031

Gebru H (2015) A review on the comparative advantages of intercropping to mono-cropping system. J Biol Agric Healthc 5:1-13

Giles CD, Richardson AE, Cade-Menun BJ et al (2018) Phosphorus acquisition by citrate- and phytase-exuding Nicotiana tabacum plant mixtures depends on soil phosphorus availability and root intermingling. Physiol Plant 163:356-371. https://doi.org/10.1111/ppl.12718
Gong X, Dang K, Lv S et al (2020) Interspecific root interactions and water-use efficiency of intercropped proso millet and mung bean. Eur J Agron 115:126034. https://doi. org/10.1016/j.eja.2020.126034

Hao W, Ren L, Ran W, Shen Q (2010) Allelopathic effects of root exudates from watermelon and rice plants on Fusarium oxysporum f.sp. niveum. Plant Soil 336:485-497. https://doi.org/10.1007/s11104-010-0505-0

Hassan A, Dresbøll DB, Rasmussen CR, et al (2019) Root distribution in intercropping systems - a comparison of DNA based methods and visual distinction of roots. Arch Agron Soil Sci 0:1-14. https://doi.org/10.1080/03650 340.2019.1675872

Hauggaard-Nielsen H, Ambus P, Jensen ES (2003) The comparison of nitrogen use and leaching in sole cropped versus intercropped pea and barley. Nutr Cycl Agroecosystems 65:289-300. https://doi.org/10.1023/A:1022612528 161

Hawkins H-J, Hettasch H, West AG, Cramer MD (2009) Hydraulic redistribution by Protea 'Sylvia' (Proteaceae) facilitates soil water replenishment and water acquisition by an understorey grass and shrub. Funct Plant Biol 36:752-760. https://doi.org/10.1071/FP09046

Heijden MGAVD, Horton TR (2009) Socialism in soil? The importance of mycorrhizal fungal networks for facilitation in natural ecosystems. J Ecol 97:1139-1150. https:// doi.org/10.1111/j.1365-2745.2009.01570.x

Hinsinger P (2001) Bioavailability of soil inorganic P in the rhizosphere as affected by root-induced chemical changes: a review. Plant Soil 237:173-195. https://doi. org/10.1023/A:1013351617532

Hinsinger P, Betencourt E, Bernard L et al (2011) P for two, sharing a scarce resource: soil phosphorus acquisition in the rhizosphere of intercropped species. Plant Physiol 156:1078-1086. https://doi.org/10.1104/pp.111.175331

Hooks CRR, Wang K-H, Ploeg A, McSorley R (2010) Using marigold (Tagetes spp.) as a cover crop to protect crops from plant-parasitic nematodes. Appl Soil Ecol 46:307320. https://doi.org/10.1016/j.apsoil.2010.09.005

$\mathrm{Hu}$ H-Y, Li H, Hao M-M et al (2021) Nitrogen fixation and crop productivity enhancements co-driven by intercrop root exudates and key rhizosphere bacteria. New Phytol (early View). https://doi.org/10.1111/1365-2664.13964

Inal A, Gunes A, Zhang F, Cakmak I (2007) Peanut/maize intercropping induced changes in rhizosphere and nutrient concentrations in shoots. Plant Physiol Biochem 45:350-356. https://doi.org/10.1016/j.plaphy.2007.03. 016

Isaac ME, Borden KA (2019) Nutrient acquisition strategies in agroforestry systems. Plant Soil 444:1-19. https://doi. org/10.1007/s11104-019-04232-5

Isakson SR (2009) No hay ganancia en la milpa: the agrarian question, food sovereignty, and the on-farm conservation of agrobiodiversity in the Guatemalan highlands. J Peasant Stud 36:725-759. https://doi.org/10.1080/03066 150903353876

Islam AM, Adjesiwor AT (2018) Nitrogen fixation and transfer in agricultural production systems. In: Nitrogen in Agriculture: Updates

Izumi Y, Okaichi S, Awala SK et al (2018) Water supply from pearl millet by hydraulic lift can mitigate drought stress 
and improve productivity of rice by the close mixed planting. Plant Prod Sci 21:8-15. https://doi.org/10.1080/ 1343943X.2018.1428494

Jensen ES, Bedoussac L, Carlsson G et al (2015) Enhancing yields in organic crop production by eco-functional intensification. Sustain Agric Res 4:42. https://doi.org/ 10.5539/sar.v4n3p42

Johnson SN, Benefer CM, Frew A et al (2016) New frontiers in belowground ecology for plant protection from rootfeeding insects. Appl Soil Ecol 108:96-107. https://doi. org/10.1016/j.apsoil.2016.07.017

Kong C, Liang W, Hu F et al (2004) Allelochemicals and their transformations in the Ageratum conyzoides intercropped citrus orchard soils. Plant Soil 264:149-157. https://doi. org/10.1023/B:PLSO.0000047759.65133.fa

Kowalchuk GA, Buma DS, de Boer W, et al (2002) Effects of above-ground plant species composition and diversity on the diversity of soil-borne microorganisms. Antonie Van Leeuwenhoek 81:509. https://doi.org/10.1023/A:10205 65523615

Lacombe S, Bradley RL, Hamel C, Beaulieu C (2009) Do treebased intercropping systems increase the diversity and stability of soil microbial communities? Agric Ecosyst Environ 131:25-31. https://doi.org/10.1016/j.agee.2008. 08.010

Li L, Sun J, Zhang F et al (2001a) Wheat/maize or wheat/soybean strip intercropping: I. Yield advantage and interspecific interactions on nutrients. Field Crops Res 71:123137. https://doi.org/10.1016/S0378-4290(01)00156-3

Li L, Sun J, Zhang F et al (2001b) Wheat/maize or wheat/ soybean strip intercropping: II. Recovery or compensation of maize and soybean after wheat harvesting. Field Crops Res 71:173-181. https://doi.org/10.1016/S03784290(01)00157-5

Li SM, Li L, Zhang FS, Tang C (2004) Acid phosphatase role in chickpea/maize intercropping. Ann Bot 94:297-303. https://doi.org/10.1093/aob/mch140

Li L, Sun J, Zhang F et al (2006) Root distribution and interactions between intercropped species. Oecologia 147:280290. https://doi.org/10.1007/s00442-005-0256-4

Li L, Li S-M, Sun J-H et al (2007) Diversity enhances agricultural productivity via rhizosphere phosphorus facilitation on phosphorus-deficient soils. Proc Natl Acad Sci 104:11192-11196. https://doi.org/10.1073/pnas.07045 91104

Li H, Zhang F, Rengel Z, Shen J (2013) Rhizosphere properties in monocropping and intercropping systems between faba bean (Vicia faba L.) and maize (Zea mays L.) grown in a calcareous soil. Crop Pasture Sci 64:976-984. https://doi.org/10.1071/CP13268

Li L, Tilman D, Lambers H, Zhang F-S (2014) Plant diversity and overyielding: insights from belowground facilitation of intercropping in agriculture. New Phytol 203:63-69. https://doi.org/10.1111/nph.12778

Li C, Dong Y, Li H et al (2016a) Shift from complementarity to facilitation on $\mathrm{P}$ uptake by intercropped wheat neighboring with faba bean when available soil $\mathrm{P}$ is depleted. Sci Rep 6:1-8. https://doi.org/10.1038/srep18663

Li B, Li Y-Y, Wu H-M et al (2016b) Root exudates drive interspecific facilitation by enhancing nodulation and $\mathrm{N} 2$ fixation. Proc Natl Acad Sci 113:6496-6501. https://doi. org/10.1073/pnas.1523580113

Li C, Kuyper TW, van der Werf W et al (2019) Testing for complementarity in phosphorus resource use by mixtures of crop species. Plant Soil 439:163-177. https://doi.org/ 10.1007/s11104-018-3732-4

Li C, Hoffland E, Kuyper TW et al (2020a) Syndromes of production in intercropping impact yield gains. Nat Plants 6:653-660. https://doi.org/10.1038/s41477-020-0680-9

Li C, Hoffland E, Kuyper TW et al (2020b) Yield gain, complementarity and competitive dominance in intercropping in China: A meta-analysis of drivers of yield gain using additive partitioning. Eur J Agron 113:125987. https://doi.org/10.1016/j.eja.2019.125987

Lithourgidis AS, Dordas CA, Damalas CA, Vlachostergios DN (2011) Annual intercrops: an alternative pathway for sustainable agriculture. Aust J Crop Sci 5:16

Liu Y-X, Zhang W-P, Sun J-H et al (2015) High morphological and physiological plasticity of wheat roots is conducive to higher competitive ability of wheat than maize in intercropping systems. Plant Soil 397:387-399. https:// doi.org/10.1007/s11104-015-2654-7

Liu S, Remley M, Nichols RL et al (2019) Morphological traits underlying differences in early vigor among four cotton genotypes. Crop Sci 59:1165-1181. https://doi.org/10. 2135/cropsci2018.10.0611

Liu M, Li H, Song J et al (2020a) Interactions between intercropped Avena sativa and Agropyron cristatum for nitrogen uptake. Plant Soil 447:611-621. https://doi.org/10. 1007/s11104-019-04389-Z

Liu Y-X, Sun J-H, Zhang F-F, Li L (2020b) The plasticity of root distribution and nitrogen uptake contributes to recovery of maize growth at late growth stages in wheat/ maize intercropping. Plant Soil 447:39-53. https://doi. org/10.1007/s11104-019-04034-9

Loreau M, Hector A (2001) Partitioning selection and complementarity in biodiversity experiments. Nature 412:7276. https://doi.org/10.1038/35083573

Louarn G, Barillot R, Combes D, Escobar-Gutiérrez A (2020) Towards intercrop ideotypes: non-random trait assembly can promote overyielding and stability of species proportion in simulated legume-based mixtures. Ann Bot. https://doi.org/10.1093/aob/mcaa014

Ma L, Li Y, Wu P et al (2019) Effects of varied water regimes on root development and its relations with soil water under wheat/maize intercropping system. Plant Soil 439:113-130. https://doi.org/10.1007/ s11104-018-3800-9

Martín-Robles N, Morente-López J, Freschet GT et al (2019) Root traits of herbaceous crops: Pre-adaptation to cultivation or evolution under domestication? Funct Ecol 33:273-285. https://doi.org/10.1111/1365-2435.13231

Matimati I, Anthony Verboom G, Cramer MD (2014) Do hydraulic redistribution and nocturnal transpiration facilitate nutrient acquisition in Aspalathus linearis? Oecologia 175:1129-1142. https://doi.org/10.1007/ s00442-014-2987-6

Meiners SJ, Kong C-H, Ladwig LM et al (2012) Developing an ecological context for allelopathy. Plant Ecol 213:12211227. https://doi.org/10.1007/s11258-012-0078-5 
Mikić A, Ćupina B, Rubiales D et al (2015) Models, developments, and perspectives of mutual legume intercropping. In: Sparks DL (ed) Advances in Agronomy. Academic Press, pp 337-419

Mommer L, Cotton TEA, Raaijmakers JM et al (2018) Lost in diversity: the interactions between soil-borne fungi, biodiversity and plant productivity. New Phytol 218:542553. https://doi.org/10.1111/nph.15036

Montesinos-Navarro A, Segarra-Moragues JG, Valiente-Banuet A, Verdú M (2012) Plant facilitation occurs between species differing in their associated arbuscular mycorrhizal fungi. New Phytol 196:835-844. https://doi.org/10. 1111/j.1469-8137.2012.04290.x

Mu Y, Chai Q, Yu A et al (2013) Performance of wheat/maize intercropping is a function of belowground interspecies interactions. Crop Sci 53:2186-2194. https://doi.org/10. 2135/cropsci2012.11.0619

Nagy R, Vasconcelos MJV, Zhao S et al (2006) Differential regulation of five Pht1 phosphate transporters from maize (Zea mays L.). Plant Biol 8:186-197. https://doi. org/10.1055/s-2005-873052

Neykova N, Obando J, Schneider R et al (2011) Vertical root distribution in single-crop and intercropping agricultural systems in Central Kenya. J Plant Nutr Soil Sci 174:742749. https://doi.org/10.1002/jpln.201000314

Pang J, Wang Y, Lambers H et al (2013) Commensalism in an agroecosystem: hydraulic redistribution by deep-rooted legumes improves survival of a droughted shallow-rooted legume companion. Physiol Plant 149:79-90. https://doi. org/10.1111/ppl.12020

Peoples MB, Chalk PM, Unkovich MJ, Boddey RM (2015) Can differences in $15 \mathrm{~N}$ natural abundance be used to quantify the transfer of nitrogen from legumes to neighbouring non-legume plant species? Soil Biol Biochem 87:97-109. https://doi.org/10.1016/j.soilbio.2015.04.010

Pigliucci M (2001) Phenotypic plasticity: beyond nature and nurture. JHU Press

Pirhofer-Walzl K, Rasmussen J, Høgh-Jensen H et al (2012) Nitrogen transfer from forage legumes to nine neighbouring plants in a multi-species grassland. Plant Soil 350:71-84. https://doi.org/10.1007/s11104-011-0882-z

Prieto I, Armas C, Pugnaire FI (2012) Water release through plant roots: new insights into its consequences at the plant and ecosystem level. New Phytol 193:830-841. https://doi.org/10.1111/j.1469-8137.2011.04039.x

Qin A, Huang G, Chai Q et al (2013) Grain yield and soil respiratory response to intercropping systems on arid land. Field Crops Res 144:1-10. https://doi.org/10.1016/j.fcr. 2012.12.005

Rabbi SMF, Guppy CN, Tighe MK et al (2017) Root architectural responses of wheat cultivars to localised phosphorus application are phenotypically similar. J Plant Nutr Soil Sci 180:169-177. https://doi.org/10.1002/jpln.20160 0503

Raseduzzaman Md, Jensen ES (2017) Does intercropping enhance yield stability in arable crop production? A meta-analysis. Eur J Agron 91:25-33. https://doi.org/10. 1016/j.eja.2017.09.009

Ratnadass A, Fernandes P, Avelino J, Habib R (2012) Plant species diversity for sustainable management of crop pests and diseases in agroecosystems: a review. Agron
Sustain Dev 32:273-303. https://doi.org/10.1007/ s13593-011-0022-4

Ren LX, Su SM, Yang XM, Xu YC, Huang QW, Shen QR (2008) Intercropping with aerobic rice suppressed Fusarium wilt in watermelon. Soil Biol Biochem 40:834-844

Ren L, Lou Y, Zhang N et al (2013) Role of arbuscular mycorrhizal network in carbon and phosphorus transfer between plants. Biol Fertil Soils 49:3-11. https://doi.org/ 10.1007/s00374-012-0689-y

Ren YY, Wang XL, Zhang SQ et al (2017) Influence of spatial arrangement in maize-soybean intercropping on root growth and water use efficiency. Plant Soil 415:131-144. https://doi.org/10.1007/s11104-016-3143-3

Riaz T, Javaid A (2017) Mixed cropping effects on agronomic parameters and mycorrhizal status of Gladiolus grandiflorus hort. and Narcissus papyraceus ker-gawl. Bangladesh J Bot 46(1):133-138

Richards JH, Caldwell MM (1987) Hydraulic lift: substantial nocturnal water transport between soil layers by Artemisia tridentata roots. Oecologia 73:486-489. https://doi. org/10.1007/BF00379405

Richardson AE, Hocking PJ, Simpson RJ, George TS (2009) Plant mechanisms to optimise access to soil phosphorus. Crop Pasture Sci 60(2):124-143

Rioba NB, Stevenson PC (2017) Ageratum conyzoides L. for the management of pests and diseases by small holder farmers. Ind Crops Prod 110:22-29. https://doi.org/10. 1016/j.indcrop.2017.06.068

Schiffers K, Tielbörger K, Tietjen B, Jeltsch F (2011) Root plasticity buffers competition among plants: theory meets experimental data. Ecology 92:610-620. https://doi.org/ 10.1890/10-1086.1

Schöb C, Kerle S, Karley A et al (2015) Intra-specific genetic diversity and composition modify species-level diversityproductivity relationships. New Phytol 205:720-730. https://doi.org/10.1111/nph.13043

Selosse M-A, Richard F, He X, Simard SW (2006) Mycorrhizal networks: des liaisons dangereuses? Trends Ecol Evol 21:621-628. https://doi.org/10.1016/j.tree.2006.07.003

Singh D, Mathimaran N, Boller T, Kahmen A (2019) Bioirrigation: a common mycorrhizal network facilitates the water transfer from deep-rooted pigeon pea to shallowrooted finger millet under drought. Plant Soil 440:277292. https://doi.org/10.1007/s11104-019-04082-1

Snyder KA, James JJ, Richards JH, Donovan LA (2008) Does hydraulic lift or nighttime transpiration facilitate nitrogen acquisition? Plant Soil 306:159-166. https://doi.org/10. 1007/s11104-008-9567-7

Solanki MK, Wang F-Y, Wang Z et al (2019) Rhizospheric and endospheric diazotrophs mediated soil fertility intensification in sugarcane-legume intercropping systems. J Soils Sediments 19:1911-1927. https://doi.org/10.1007/ s11368-018-2156-3

Song YN, Marschner P, Li L et al (2007a) Community composition of ammonia-oxidizing bacteria in the rhizosphere of intercropped wheat (Triticum aestivum L.), maize (Zea mays L.), and faba bean (Vicia faba L.). Biol Fertil Soils 44:307-314. https://doi.org/10.1007/s00374-007-0205-y

Song YN, Zhang FS, Marschner P et al (2007b) Effect of intercropping on crop yield and chemical and microbiological properties in rhizosphere of wheat (Triticum aestivum 
L.), maize (Zea mays L.), and faba bean (Vicia faba L.). Biol Fertil Soils 43:565-574. https://doi.org/10.1007/ s00374-006-0139-9

Stomph T, Dordas C, Baranger A et al (2020) Designing intercrops for high yield, yield stability and efficient use of resources: Are there principles? In: Sparks DL (ed) Advances in Agronomy. Academic Press, pp 1-50

Streit J, Meinen C, Rauber R (2019) Intercropping effects on root distribution of eight novel winter faba bean genotypes mixed with winter wheat. Field Crops Res 235:110. https://doi.org/10.1016/j.fcr.2019.02.014

Sun Y, Bi H, Xu H, et al (2018) Variation of fine roots distribution in apple (Malus pumila M.)-crop intercropping systems on the Loess Plateau of China. Agronomy 8:280. https://doi.org/10.3390/agronomy8120280

Sun B, Gao Y, Yang H et al (2019) Performance of alfalfa rather than maize stimulates system phosphorus uptake and overyielding of maize/alfalfa intercropping via changes in soil water balance and root morphology and distribution in a light chernozemic soil. Plant Soil 439:145-161. https://doi.org/10.1007/s11104-018-3888-y

Tang C, Robson AD, Dilworth MJ (1990) The role of iron in nodulation and nitrogen fixation in Lupinus angustifolius L. New Phytol 114:173-182. https://doi.org/10.1111/j. 1469-8137.1990.tb00388.x

Tang X, Zhang C, Yu Y et al (2020) Intercropping legumes and cereals increases phosphorus use efficiency; a meta-analysis. Plant Soil. https://doi.org/10.1007/ s11104-020-04768-x

Thilakarathna MS, McElroy MS, Chapagain T et al (2016) Belowground nitrogen transfer from legumes to nonlegumes under managed herbaceous cropping systems. A Review Agron Sustain Dev 36:58. https://doi.org/10. 1007/s13593-016-0396-4

Thorup-Kristensen K, Halberg N, Nicolaisen M et al (2020) Digging deeper for agricultural resources, the value of deep rooting. Trends Plant Sci 25:406-417. https://doi. org/10.1016/j.tplants.2019.12.007

Trinchera A, Testani E, Ciaccia C et al (2017) Effects induced by living mulch on rhizosphere interactions in organic artichoke: The cultivar's adaptive strategy. Renew Agric Food Syst 32:214-223. https://doi.org/10.1017/S1742 170516000119

Tsay TT, Wu ST, Lin YY (2004) Evaluation of Asteraceae plants for control of Meloidogyne incognita. J Nematol 36:36-41

Tsialtas IT, Baxevanos D, Vlachostergios DN et al (2018) Cultivar complementarity for symbiotic nitrogen fixation and water use efficiency in pea-oat intercrops and its effect on forage yield and quality. Field Crops Res 226:28-37. https://doi.org/10.1016/j.fcr.2018.07.005

Turner BL (2008) Resource partitioning for soil phosphorus: a hypothesis. J Ecol 96:698-702. https://doi.org/10.1111/j. 1365-2745.2008.01384.x

Valiente-Banuet A, Verdú M (2008) Temporal shifts from facilitation to competition occur between closely related taxa. J Ecol 96:489-494. https://doi.org/10.1111/j.13652745.2008.01357.x

Valiente-Banuet A, Rumebe AV, Verdú M, Callaway RM (2006) Modern Quaternary plant lineages promote diversity through facilitation of ancient Tertiary lineages.
Proc Natl Acad Sci 103:16812-16817. https://doi.org/10. 1073/pnas.0604933103

Vance CP, Uhde-Stone C, Allan DL (2003) Phosphorus acquisition and use: critical adaptations by plants for securing a nonrenewable resource. New Phytol 157:423-447. https://doi.org/10.1046/j.1469-8137.2003.00695.x

Vijaya Bhaskar AV, Weedon OD, Finckh MR (2019) Exploring the differences between organic and conventional breeding in early vigour traits of winter wheat. Eur J Agron 105:86-95. https://doi.org/10.1016/j.eja.2019.01.008

Volder A, van Iersel M (2019) Root growth, physiology, and potential impact of soilless culture on their functioning. In: Raviv M, Lieth JH, Bar-Tal A (eds) Soilless Culture, 2nd edn. Elsevier, Boston, pp 15-32

Voss-Fels KP, Snowdon RJ, Hickey LT (2018) Designer roots for future crops. Trends Plant Sci 23:957-960. https:// doi.org/10.1016/j.tplants.2018.08.004

Wahbi S, Maghraoui T, Hafidi M et al (2016) Enhanced transfer of biologically fixed $\mathrm{N}$ from faba bean to intercropped wheat through mycorrhizal symbiosis. Appl Soil Ecol 107:91-98. https://doi.org/10.1016/j.apsoil.2016.05.008

Wang Y, Qin Y, Chai Q, et al (2018) Interspecies interactions in relation to root distribution across the rooting profile in wheat-maize intercropping under different plant densities. Front Plant Sci. https://doi.org/10.3389/fpls.2018. 00483

Weiner J (2004) Allocation, plasticity and allometry in plants. Perspect Plant Ecol Evol Syst 6:207-215. https://doi.org/ 10.1078/1433-8319-00083

Xiao X, Cheng Z, Meng H, et al (2012) Intercropping with garlic alleviated continuous cropping obstacle of cucumber in plastic tunnel. Acta Agric Scand Sect B - Soil Plant Sci 62:696-705. https://doi.org/10.1080/09064710.2012. 697571

Xue Y, Xia H, Christie P et al (2016) Crop acquisition of phosphorus, iron and zinc from soil in cereal/legume intercropping systems: a critical review. Ann Bot 117:363377. https://doi.org/10.1093/aob/mcv182

Yan S, Du X, Wu F et al (2014) Proteomics insights into the basis of interspecific facilitation for maize (Zea mays) in faba bean (Vicia faba)/maize intercropping. J Proteomics 109:111-124. https://doi.org/10.1016/j.jprot.2014.06.027

Yang T, Zhu Y, Duan ZP et al (2019) Root distribution and productivity in a poplar tree + alfalfa silvopastoral system in northwest China's Xinjiang Province. Agrofor Syst. https://doi.org/10.1007/s10457-019-00466-5

Yu R-P, Li X-X, Xiao Z-H et al (2020) Phosphorus facilitation and covariation of root traits in steppe species. New Phytol 226:1285-1298. https://doi.org/10.1111/nph.16499

Zadworny M, McCormack ML, Mucha J et al (2016) Scots pine fine roots adjust along a 2000-km latitudinal climatic gradient. New Phytol 212:389-399. https://doi.org/ 10.1111/nph. 14048

Zhang FS, Li L, Sun JH (2001) Contribution of above- and below-ground interactions to intercropping. Plant Nutrition: Food security and sustainability of agro-ecosystems through basic and applied research. Springer, Netherlands, Dordrecht, pp 978-979

Zhang F, Shen J, Zhang J, Zuo Y, Li L, Chen X (2010) Rhizosphere processes and management for improving nutrient use efficiency and crop productivity: implications for 
China. Adv Agron 107:1-32. https://doi.org/10.1016/ S0065-2113(10)07001-X

Zhang W, Ahanbieke P, Wang BJ et al (2013) Root distribution and interactions in jujube tree/wheat agroforestry system. Agrofor Syst 87:929-939. https://doi.org/10.1007/ s10457-013-9609-x

Zhang W, Ahanbieke P, Wang BJ et al (2015) Temporal and spatial distribution of roots as affected by interspecific interactions in a young walnut/wheat alley cropping system in northwest China. Agrofor Syst 89:327-343. https://doi.org/10.1007/s10457-014-9770-x

Zhang D, Zhang C, Tang X et al (2016) Increased soil phosphorus availability induced by faba bean root exudation stimulates root growth and phosphorus uptake in neighbouring maize. New Phytol 209:823-831. https://doi.org/ $10.1111 / \mathrm{nph} .13613$

Zhang D, Li H, Fu Z, et al (2019a) Increased planting density of Chinese milk vetch (Astragalus sinicus) weakens phosphorus uptake advantage by rapeseed (Brassica napus) in a mixed cropping system. AoB Plants. https:// doi.org/10.1093/aobpla/plz033

Zhang W, Wang BJ, Gan YW et al (2019b) Competitive interaction in jujube tree/cotton agroforestry system in Xinjiang province, northwestern China. Agrofor Syst 93:591605. https://doi.org/10.1007/s10457-017-0153-y

Zhang D, Lyu Y, Li H et al (2020a) Neighbouring plants modify maize root foraging for phosphorus: coupling nutrients and neighbours for improved nutrient-use efficiency. New Phytol 226:244-253. https://doi.org/10.1111/nph. 16206

Zhang H, Wang X, Gao Y, Sun B (2020b) Short-term N transfer from alfalfa to maize is dependent more on arbuscular mycorrhizal fungi than root exudates in $\mathrm{N}$ deficient soil. Plant Soil 446:23-41. https://doi.org/10.1007/ s11104-019-04333-1

Zhang W-P, Gao S-N, Li Z-X et al (2021) Shifts from complementarity to selection effects maintain high productivity in maize/legume intercropping systems (Early View). https://doi.org/10.1111/1365-2664.13989

Zhou Y, Cen H, Tian D et al (2019) A tomato and tall fescue intercropping system controls tomato stem rot. J Plant Interact 14:637-647. https://doi.org/10.1080/17429145. 2019.1689582

Zhu S, Morel J-B (2018) Molecular mechanisms underlying microbial disease control in intercropping. Mol Plant Microbe Interact 32:20-24. https://doi.org/10.1094/ MPMI-03-18-0058-CR

Zhu J, Zhang C, Lynch JP (2010) The utility of phenotypic plasticity of root hair length for phosphorus acquisition. Funct Plant Biol 37:313-322. https://doi.org/10.1071/ FP09197

Zhu YH, Weiner J, Yu MX, Li FM (2019) Evolutionary agroecology: trends in root architecture during wheat breeding. Evol Appl 12(4):733-743. https://doi.org/10.1111/ eva. 12749

Zou X, Li H, Sun Z et al (2019) Interspecific facilitation between intercropped millets and peanuts: insights from root proteomics analysis. Arch Agron Soil Sci 65:612624. https://doi.org/10.1080/03650340.2018.1514600

Zuo Y, Zhang F (2008) Effect of peanut mixed cropping with gramineous species on micronutrient concentrations and iron chlorosis of peanut plants grown in a calcareous soil. Plant Soil 306:23-36. https://doi.org/10.1007/ s11104-007-9484-1

Zuo Y, Zhang F (2009) Iron and zinc biofortification strategies in dicot plants by intercropping with gramineous species. A Review Agron Sustain Dev 29:63-71. https://doi.org/ 10.1051/agro:2008055

Publisher's Note Springer Nature remains neutral with regard to jurisdictional claims in published maps and institutional affiliations. 